\title{
A banki hitelezést meghatározó tényezők - középpontban a bankok helyzete és a makrokörnyezet
}

\begin{abstract}
A hazai bankrendszer hitelállománya hat évvel a válság kezdete után is csökken. 11 hazai bank 1999 és 2013 közötti adatait tartalmazó paneladatbázis segítségével vizsgáljuk, hogy milyen tényezők állnak e folyamat mögött. Eredményeink azt igazolják, hogy a jó finanszírozási pozíció (hitel/betét mutató) támogatja a hitelezési aktivitást. A likviditási kockázat egyéb jellemzői - mint a devizacsere-ügyletekre való ráutaltság - pedig negatívan hatnak a hitelezésre. Az, hogy van-e stratégiai külföldi tulajdonosa a banknak, nem meghatározó a hitelezési aktivitásban, de a tulajdonos bankcsoport helyzete már fontos tényező. Azok a bankok hiteleznek aktívabban, amelyek anyabankjának jövedelmezősége magasabb, tőkeellátottsága jobb, illetve amelynek a finanszírozási pozíciója biztosabb. A válsággal ezek az összefüggések némiképp megváltoztak. 2009 után a szolvenciahelyzet meghatározóbbá vált a hitelezési aktivitásban, míg a likviditási pozíció szerepe csökkent. Journal of Economic Literature (JEL) kód: E44, E51, G21, G28.
\end{abstract}

\section{Bevezetés}

A 2000-es évek elejére a kelet-közép-európai régióban lezárult a bankrendszerek átalakulása. Ennek eredményeként a régió összes országában a külföldi dominancia jellemezte a bankrendszert. A külföldi szereplők megjelenése nemcsak azért volt fontos, mert tőkével és likviditással látták el a régió bankrendszereit, hanem mert a banki know-how-t is biztosították (lásd bővebben Banai és szerzőtársai [2010a]). Erre alapozva a régió országaiban gyors felzárkózás és dinamikus hitelezés volt megfigyelhetö. A globális likviditásbőség ugyancsak segítette a régió hitelexpanzióját. Bár a válság előtti fejlődéstörténet a régió országai között nagyon hasonló volt, a válság sok szempontból eltérően érintette őket. A Lehman-csőd után a piaci szektornak nyújtott hitelállomány gyors tempóban kezdett szükülni a kelet-közép-európai országokban. Ez a csökkenő időszak azonban néhány országban - mint Lengyelország vagy Szlovákia nagyon rövid volt, míg máshol (például Magyarország) még mostanra sem zárult le.

Banai Ádám, a Budapesti Corvinus Egyetem doktoranduszhallgatója.

A kézirat első változata 2015. október 25-én érkezett szerkesztőségünkbe.

DOI: http://dx.doi.org/10.18414/KSZ.2016.2.137 
Tanulmányunkban a hitelezési aktivitást meghatározó tényezőket vizsgáljuk a magyar bankrendszerben. Elemzésünk központi kérdése a banki likviditási pozíció szerepe a hitelezésben. Összeállítottunk egy egyedi paneladatbázist, ami tartalmazza a legfontosabb 11 magyar bank föbb tulajdonságait az 1999-től 2013 végéig tartó időszakban. Az adatbázist a külföldi tulajdonú bankok esetén az anyabank csoportjára vonatkozó információkkal is kiegészítettük, hogy tesztelni tudjuk azt a nézetet, amely szerint a leánybanki üzleti döntésekben meghatározó szerepük van a tulajdonosoknak. Végül a válsághatásokat is elemeztük. A tanulmányban megállapítjuk, hogy a hitelezési aktivitásban kiemelt szerepe van a likviditási pozíciónak. A magas hitel/betét arány akadályozza a hitelezést. A likviditási kockázat más formáinak (például a devizacsere-ügyletekre való ráutaltság vagy a likvid eszközök állománya) magyarázóereje ugyancsak jelentős. Az egyedi banki tulajdonságok mellett a tulajdonoscsoport finanszírozási, tőke- és jövedelmezőségi helyzete is szignifikáns hatással van a leánybank hitelezési tevékenységére. Végül, megmutatjuk, hogy ezek az összefüggések némiképp megváltoztak a válság hatására. 2009 után a banki tulajdonságok közül a szolvenciahelyzet sokkal inkább meghatározó volt a hitelezési aktivitásban, mint a likviditási pozíció.

Banai és szerzőtársai [2010b] tanulmány elemezte a magyar bankok viselkedését a válság előtt és alatt, de empirikus kutatást nem végzett a témában. Leíró statisztikák alapján megállapította, hogy a magyar bankok kockázatvállalási hajlandósága nagyon magas volt a válság előtt, ami hitelezési boomhoz vezetett. Az e bankok közötti versenyt elsősorban az egyre nagyobb kockázat vállalása határozta meg. Az ügyfelek megszerzéséért fokozatosan lazították a hitelfeltételeket (például a hitelfedezeti arány - loan to value, $L T V$ - jelentös mértékben megemelkedett a háztartási hiteleknél 2004 és 2008 között). Ezzel egy időben a devizaalapú hitelek lettek a legnépszerübb termékek mind a háztartások, mind a vállalatok körében. Erre a problémára több más tanulmány (például Király és szerzőtársai [2008] vagy Király-Nagy [2008]) is felhívta a figyelmet. Finanszírozási oldalról a hitelezés felfutását jelentős mértékben megnőtt likviditási kockázatok kísérték. A kialakult kockázat pedig a válság kezdetétől gátolta a hitelezést. Elemzésünk empirikusan is bizonyítja ezt a nézetet. Banai és szerzőtársaival [2010b] ugyancsak összhangban azt is megállapítjuk, hogy a válság során a szolvenciahelyzet egyre fontosabbá vált.

A magyarországi banki hitelezéssel különböző szempontok szerint több empirikus tanulmány is foglalkozott. Sóvágó [2011] például a keresleti és kínálati hatásokat igyekezett azonosítani a hitelezési dinamikában. Hosszú és szerzőtársai [2015] hitelrések meghatározására mutatott be egy lehetséges módszert. A likviditás hitelezésben betöltött szerepének vizsgálata azonban eddig elmaradt. A nemzetközi irodalomban találunk olyan tanulmányokat, amelyek a banki hitelezést meghatározó tényezőket igyekeznek feltárni. Cornett és szerzőtársai [2011] például az amerikai bankok viselkedését elemezte a válság korai szakaszában. A szerzők igazolták, hogy a bankok hitelpolitikával kapcsolatos döntéseiben kiemelt szerepe van a likviditási helyzetnek: azok a bankok voltak aktívabb hitelezők, a melyeknek több volt a stabil forrásuk - ezzel tanulmányunk megállapításai is összhangban vannak. 
Aydin [2008] a hitelezést befolyásoló tényezőket vizsgálta a válság előtti időszakban. A szerző egyedi banki adatokat használt, amelyek a kelet-közép-európai régió 10 országának 72 intézményét fedték le, a 2007-ig tartó megfigyelési időszak miatt a válság hatásait értelemszerủen nem elemezte. Az eredmények alapján látható, hogy a külföldi bankok megjelenése miatt a bankok számára könnyebbé vált a forrásszerzés, ami serkentette a hitelezést. Ez arra is utal, hogy a válság előtt nem volt lényeges a külföldi bankok által dominált bankrendszerekben a tényleges finanszírozási helyzet, hiszen a hitelintézetek könnyen jutottak külső forráshoz. Ez ellentétes a magyar bankrendszerre végzett vizsgálatunk eredményeivel. Számításaink szerint az egyedi banki hitel/betét mutató szignifikáns hatással van a hitelezésre.

A válság jelentős mértékben megváltoztatta a kelet-közép-európai bankrendszerek helyzetét. A különböző országokban tapasztalt hitelezési dinamikák nagymértékben eltértek. Temesváry-Banai [2015] a kelet-közép-európai régió országain azt vizsgálta, hogy milyen tényezők befolyásolják a banki hitelezést, Everaert és szerzötársai [2015] tanulmánnyal összhangban igazolta, hogy a jó portfólióminőség és az erős tőkehelyzet szükséges feltétele az aktívabb hitelezésnek. Emellett a szerzőpáros elemezte a tulajdonoscsoportok helyzetének hatásait is. Megállapította, hogy a válság előtt a régiós leánybankjaikon keresztül nagyobb likviditási kockázatot vállaló bankcsoportok aktívabbnak bizonyultak, a válság kezdetétől azonban a jobb finanszírozási helyzet eredményezett intenzívebb hitelezést. Némiképp ellentmondva a Banai és szerzőtársai [2010a] és Everaert és szerzőtársai [2015] tanulmánynak Temesváry-Banai [2015] hangsúlyozta, hogy a kedvezőtlen likviditási pozícióban levő tulajdonos bankok miatt a leánybankok hitelezésének intenzitása is gyengül. Ez összhangban van Cetorelli-Goldberg [2011] megállapításaival. A mostani kutatásunknak is fontos eredménye, hogy bár önmagában a tulajdonosi struktúra nem meghatározó az egyedi hiteldinamikában, az anyabank helyzete szignifikáns hatással van a leánybank aktivitására is.

Az említett tanulmányok jól bemutatják a kelet-közép-európai régió bankrendszereit, de a széles panelelemzések elfedik egy-egy ország speciális tulajdonságait. Tanulmányunkban éppen ezért arra teszünk kísérletet, hogy a magyar helyzetről adjunk világos képet, amire a részletes adatbázisunk lehetőséget is teremt. Az eredményeink igazolják azt az álláspontunkat is, hogy régiós elemzések mellett fontos az országokat külön vizsgálni.

Magyarországon több okból is kiemelt jelentősége van a hitelezést meghatározó tényezőknek.

Az első ok: a magyar tőkepiac alulfejlett. A hitelviszonyt megtestesítő értékpapírok szerepe a vállalatok finanszírozásában elhanyagolható (1. ábra). Csak a legnagyobb vállalatok jutnak forráshoz a kötvénypiacon. Ráadásul ezek a vállalatok sok esetben külföldi tulajdonban vannak, úgyhogy számukra más lehetöségek is nyitva állnak (például az anyaintézmény banki kapcsolatain keresztül). A hazai tulajdonban levő cégek ezzel szemben döntően a magyar bankrendszerre vannak utalva. Különösen a kis- és középvállalati szektor számára - amelynek szerepe jelentős a foglalkoztatásban - fontos a bankrendszer zökkenőmentes müködése. 
1. ábra

A hitelviszonyt megtestesítő értékpapírok aránya a vállalati szektor forrásoldalán

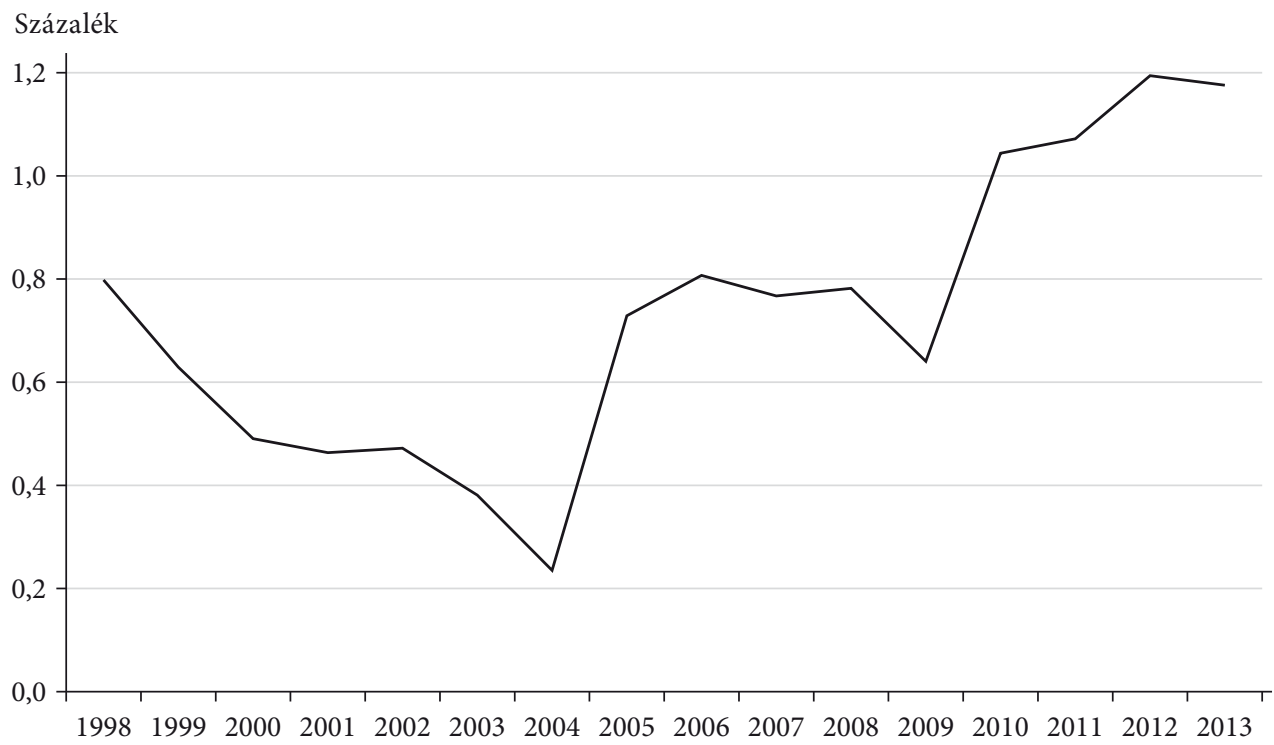

Forrás: MNB.

A második ok: a magyarországi banki hitelezés a válság kezdetétől egyre inkább elmarad a fö versenytársak (például a többi visegrádi ország) hitelezésétől. A Lehmancsőd után a többi visegrádi országban nem esett olyan látványosan a hitelezés, mint Magyarországon. ${ }^{1}$ Ennek következményeként mára a hitelállomány ezen országokban lényegesen meghaladja a válság előtti szintet. Romániában és Bulgáriában ugyancsak jobb a helyzet, mint Magyarországon. A tágabb értelemben vett régión belül csak a balti államokban és Horvátországban csökken továbbra is a hitelállomány (2. ábra). Bár az utóbbi két évben viszonylag jól teljesít a hazai gazdaság, a tapasztalatok szerint a hitel nélküli kilábalás (creditless recovery) hosszú távon törékeny lehet (Abiad és szerzőtársai [2011], Bijsterbosch-Dahlhaus [2011]).

A harmadik ok: a hazai bankok hitelezési aktivitásában is jelentős a heterogenitás. Az egyedi bankok mérlegeinek dinamikája komoly eltéréseket mutat. 2013 végén néhány bank hitelállománya meghaladta a válság előtti szint (2008. december 31.) 90 százalékát, és már elkezdett nőni. Más bankoknál még közel sincs vége a kiigazodási időszaknak, és már feleződött a hitelállomány a válság kezdete óta (3. ábra). Álláspontunk szerint e különbségeknek strukturális okai is vannak.

Tanulmányunk szerkezete a következő: a módszertani keret bemutatása után az adatbázis tulajdonságait tárgyaljuk. Ezt követően ismertetjük számításaink eredményeit, majd összegezzük megállapításainkat.

\footnotetext{
${ }^{1}$ Ezt részben magyarázhatják természetesen a hazai bankrendszer 2010 után megnövekvő terhei, amelyeket a számítások során például a mérlegföösszeg-arányos profit (ROA) mutató segítségével veszünk figyelembe.
} 


\section{2. ábra}

A hitelállomány alakulása a régióban $(2008$. december 31. $=100)$

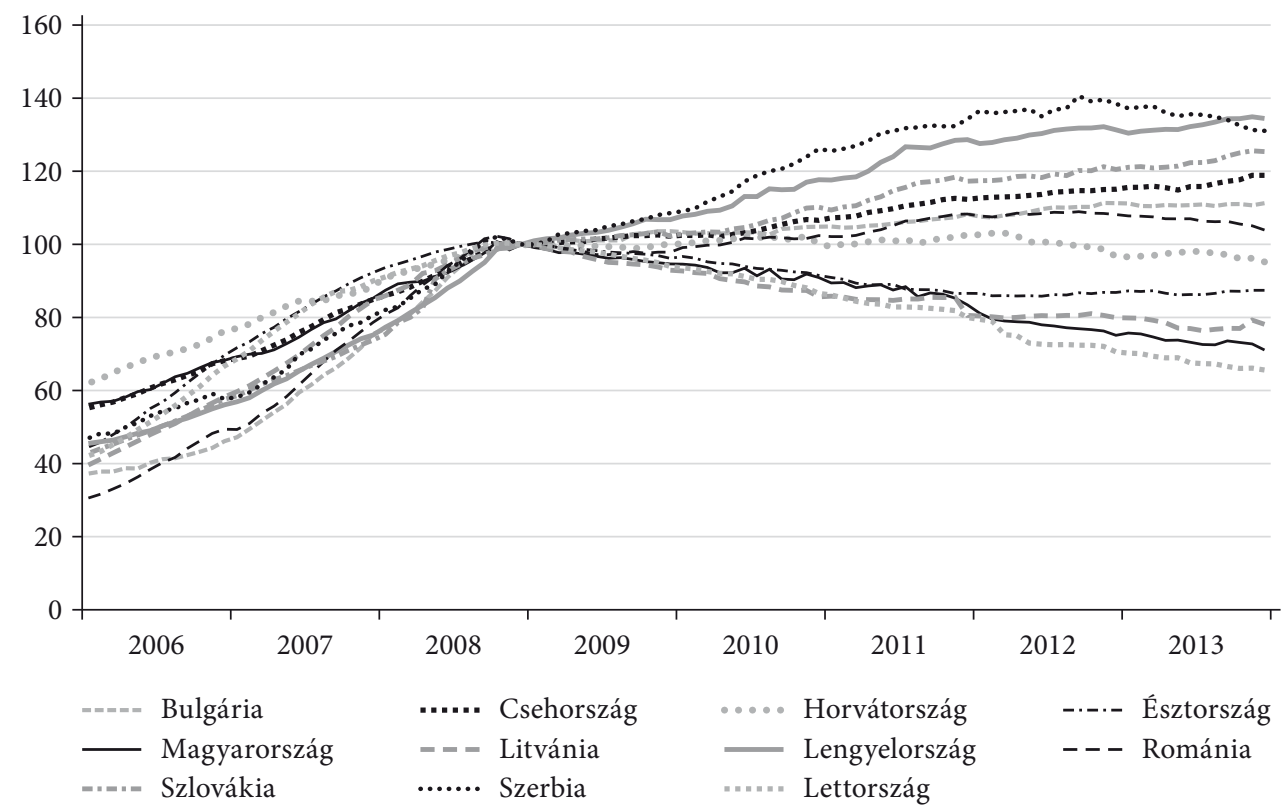

Forrás: nemzeti jegybankok.

\section{3. ábra}

A legfontosabb hazai bankok hitelállományának alakulása $(2008$. december 31. = 100)

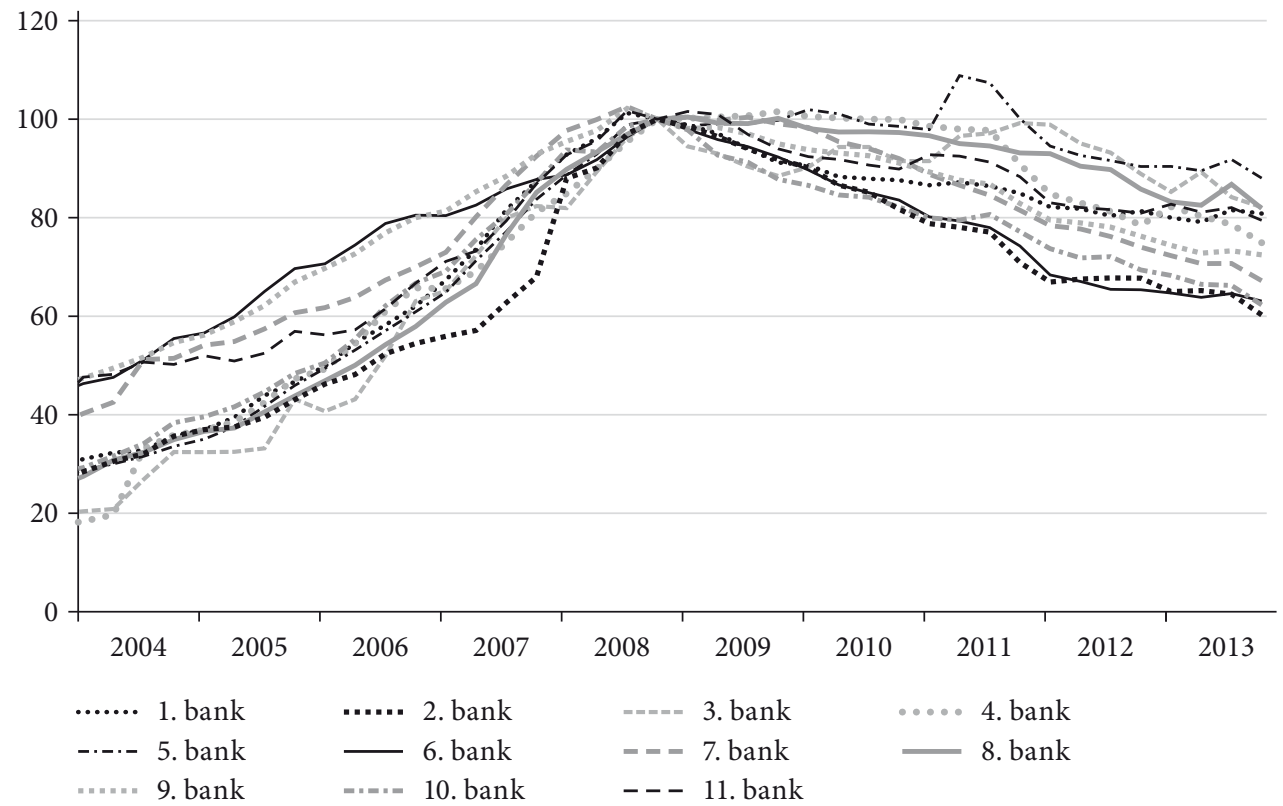

Forrás: MNB. 


\section{Módszertan}

Elemzésünkben a függő változó az éves hitelállomány-változás, vagyis a háztartási és vállalati szektornak nyújtott hitelek állományának éves százalékos változása. $L_{t}^{j}$-vel jelöljük a $j$-edik bank árfolyamszürt ${ }^{2}$ hitelállományát a $t$-edik időpontban (negyedévben). A függő változót, $l_{t}^{j}$-t a következő formában definiáljuk:

$l_{t}^{j}=\left(\ln L_{t}^{j}-\ln L_{t-4}^{j}\right) 100$.

A (2) egyenlet tartalmazza az alapspecifikációt.

$l_{t}^{j}=\alpha_{1}+\alpha_{2} Y_{t-4}^{j}+\alpha_{3} X_{t}^{j}+\varepsilon_{t}^{j}$.

A fentieknek megfelelően a függő változó az árfolyamszürt hitelállomány-változás (CREDIT GROWTH), $Y_{t-4}^{j}$ pedig a banki tulajdonságokat jelöli. Mivel negyedéves adataink vannak, és a függő változó éves változás, ezért a magyarázó változók 4 negyedéves késleltetését használjuk. (A változók meghatározását az F1. táblázat tartalmazza).

Ahogy jeleztük, a tanulmányunk fö témája a likviditás hitelezésre gyakorolt hatása, ezért több likviditási mutatót használunk, amelyek képesek megfogni a likviditási kockázat különböző formáit. Ez a mostani szabályozói törekvésekkel is összhangban van, hiszen például a Bázel-III. likviditás szabályok is többféle likviditási kockázatot átfognak (BIS [2013], [2014]).

A hitel/betét mutató (LOAN TO DEPOSIT) széles körben használt mértéke a finanszírozási struktúrának. Várakozásaink szerint a magas hitel/betét mutató hosszú távon negatív hatással van a hitelezésre. A betétek jelentik a legstabilabb finanszírozást a bankok számára, ezért szükségesek a biztonságos banki müködéshez.

A LIQUid ASSET mutató, a mérlegföösszeg-arányos likvideszköz-állomány (liquid asset to total asset) inkább a rövid távú sokkellenálló képességről ad képet. Az elözővel szemben a várt előjel ebben az esetben nem egyértelmü. A magasabb likviditási puffer egyfelől növeli a hitelezési képességet, ugyanakkor gyakran az óvatosabb hitelezési politikát jelzi.

Az FX swAP mutatót vesszük még figyelembe a likviditási változók közül, amely a nettó devizacsere-állomány mérlegföösszeg-arányos értékét (FX swap to total asset) tartalmazza. A hazai bankrendszerben csak az intézmények szűk köre rendelkezett jelentős devizacsere-állománnyal a vizsgált időszakban, ennek ellenére lehet szignifikáns hatása a hitelezésre. A devizacsere-ügyletek egyfelől csökkentik a likviditási puffer nagyságát, másfelől pedig rendszerint nagyon rövid lejáratúak, ami komoly megújítási kockázatot jelent a bankok számára (Banai és szerzőtársai [2013]). A válság alatt többször tapasztaltunk jelentős zavarokat a devizacsere-piacon, ami

\footnotetext{
${ }^{2} \mathrm{Az}$ árfolyammozgásnak jelentős hatása van Magyarországon a hitelállomány dinamikájára, hiszen a hitelek többsége devizában denominált. Éppen ezért a 2013. végi árfolyamadatot felhasználva kiszűrtük az állomány dinamikájából az árfolyamhatást.

${ }^{3}$ Ez azért is fontos, mert a felhasznált változók között egyes esetekben a fordított oksági kapcsolat is fennállhat. Így viszont ténylegesen az egyes magyarázó változók banki hitelezésre gyakorolt hatását kapjuk meg.
} 
megerősíti azt a feltételezést, hogy a devizacsere-piacra való ráutaltságnak lehet szerepe a hitelezésben.

A likviditási mutatók mellett egyéb egyedi banki változókat is figyelembe veszünk.

Az NPL mutató - a nem teljesítő hitelek állományon belül aránya - széles körben használt a portfólióminőség bemutatására. Temesváry-Banai [2015] és Everaert és szerzőtársai [2015]) egyaránt kimutatták, hogy a rosszabb portfólióminőség gyengébb hitelezési aktivitással párosul. Éppen ezért mi is negatív előjelet várunk ennél a mutatónál.

A CAPITAL ADEQUACY tőkemegfelelési mutatóval (CAR) mérjük a tőkeellátottságot, aminek ugyancsak szignifikáns hatása lehet a hitelezésre. Az előjel azonban itt is sok tényezőtől függ (például a tulajdonos bank tőkemenedzsmentje, a felügyelet müködése stb.). Ongena és szerzőtársai [2014] például bemutatták, hogy a rosszabbul tőkésített bankok aktívabban hiteleznek idegen devizában.

A тотAL ASSETS a mérlegföösszeg logaritmusa mutató segítségével vesszük figyelembe a bank méretét is. Ebben az esetben egyértelmüen negatív jelet várunk. E mögött föként egy módszertani indok áll: összegszerüen ugyanaz a nettó állományváltozás egy nagyobb intézmény esetén alacsonyabb százalékos elmozdulást jelent.

$\mathrm{Az} X^{j}$ vektor különböző kontrollváltozókat tartalmaz:

- a MERGER kétértékű változó az összeolvadásokat ragadja meg;

- a TRANSITION kétértékü változó a megfigyelt időszak első hároméves szakaszát fogja meg (ekkor még nem volt devizahitelezés);

- a CRISIS változót azért használjuk, hogy a válság okozta rezsimváltás (Everaert és szerzőtársai [2015]) ne okozzon problémát;

- a PARENT kétértékű változó szüri ki a külföldi tulajdonos esetleges speciális hatását; végül

- az EARLYREPAYMENT nevü kontrollváltozót használjuk a végtörlesztésböl adódó egyszeri jelentős állománycsökkenésre. ${ }^{5}$

A második specifikáció az előző kiterjesztett változata:

$l_{t}^{j}=\gamma_{1}+\gamma_{2} Y_{t-4}^{j}+\gamma_{3} X_{t}^{j}+\gamma_{5} M_{t}+\varepsilon_{t}^{j}$.

A keresleti oldali folyamatok és a gazdasági környezet figyelembevételéhez makrováltozókat is bevonunk, az $M$ vektor a következő változókat tartalmazza:

- a GDP GROWTH, az éves GDP-növekedés mutatója szolgál az ország gazdasági teljesítményének jellemzésére;

- az EUR/HUF árfolyam, ami részben az országkockázatról ad információt, de a devizahitelezés miatt is indokolt szerepeltetése;

- a BUBOR 3 MONTH mutató (3 hónapos Bubor) a hitelek egy részének árát jellemzi;

- a HOUSEHOLD CONFIDENCE a fogyasztói bizalmi indikátor.

${ }^{4}$ A CIB és az IEB, az FHB és az Allianz, illetve az Erste és a Posta Bank összeolvadása.

${ }^{5}$ „A kormány a magas devizakitettség miatti sérülékenység csökkentése érdekében, a deviza-jelzáloghitellel rendelkező ügyfelek számára lehetővé tette a kedvezményes árfolyam melletti végtörlesztést." (MNB [2012].) 
A modelleket megbecsüljük idő fix hatásokkal is $\left(X^{j}\right)$ : TIME FIXED EFFECT. Ezen esetekben a makrováltozók helyett a fix hatások kontrollálnak a gazdasági környezetre és keresletoldali hatásokra.

A (4) egyenletben a tulajdonos bankcsoportok helyzetét is figyelembe vesszük:

$l_{t}^{j}=\gamma_{1}+\gamma_{2} Y_{t-4}^{j}+\gamma_{3} Y_{t-4}^{j, g}+\gamma_{4} X_{t}^{j}+\gamma_{5} M_{t}+\varepsilon_{t}^{j, g}$.

Hangsúlyoznunk kell, hogy ezt a specifikációt csak egy szükebb mintán teszteltük, két okból: 1. a hazai tulajdonú bankok kimaradtak, hiszen nincs külföldi banki tulajdonosuk, 2. néhány külföldi anyabank esetén csak rövidebb időszakra áll rendelkezésre nyilvános adat.

Az $Y_{t-4}^{j, g}$ tartalmazza a tulajdonos csoport tulajdonságait:

- a LEVERAGE RATIO a tőkeáttétel mutatója,

- az NPL RATio a nem teljesítő hitelek állományon belül aránya (NPL arány);

- a CAPITAL ADEQUACY itt is a tőkemegfelelési arány (CAR) mutatója,

- a ROA mérlegföösszeg-arányos profit.

Végül külön elemezzük a válság hatását is. Az (5) egyenletben látható módon figyelembe vesszük a válságváltozó (CRISIs kétértékü változó) és a bankspecifikus, illetve makrováltozók interakcióját.

$l_{t}^{j}=\delta_{1}+C_{t}\left(\delta_{2} Y_{t-4}^{j}+\delta_{3} X_{t}^{j, g}+\delta_{4} M_{t}\right)+\varepsilon_{t}^{c}$.

Az egyedi banki változók közül néhány gyakran használt mutató - mint a jövedelmezőségi mutatók (például ROE, ROA) vagy a finanszírozási szerkezetet magyarázó mutatók (például háztartási betétek aránya) - kimaradt, mivel ezek nagyon erősen korreláltak más magyarázó változókkal. Hasonló okok miatt maradtak ki olyan makrováltozók, mint a munkanélküliségi ráta vagy a hosszú kamatok. Megfontoltuk a bankok hitelezési gyakorlatának felmérését (Survey on Bank Lending, $S L O$ ) is, de ebben az esetben nagyon leszükült a minta, hiszen csak hét bankra és lényegesen rövidebb időszakra volt adat.

\section{Adatok}

A vizsgálathoz egy paneladatbázist állítottunk össze, amely 11 magyarországi bank ${ }^{6}$ adatait tartalmazza az 1998 negyedik negyedévétől 2013 negyedik negyedévéig tartó időszakban. ${ }^{7}$ Csak olyan bankokat tettünk bele a mintába, amelyek a teljes megfi-

${ }^{6}$ OTP Bank, FHB Bank, CIB Bank, UniCredit Bank, Raiffeisen Bank, Erste Bank, K\&H bank, MKB Bank, Budapest Bank, Commerzbank és Volksbank. Bár több mint 30 bank kimaradt a mintából, ez a 11 bank a vizsgált időszakban mindig lefedte mérlegfőösszeg-arányosan a bankrendszer 90 százalékát.

${ }^{7}$ Mivel 4. késleltetéseket használunk a magyarázó változóknál, ezért a tényleges becslés az 1999 negyedik negyedévétől 2013 negyedik negyedévéig tartó (1999 Q4-2013 Q4) időszakra vonatkozik. 
gyelési időszakban aktívak voltak, és jelentősek a magyar piacon. Az alacsony piaci részesedésü, speciális igényeket kielégítő (niche) bankokat figyelmen kívül hagytuk. A vizsgált bankok hazai banki leányvállalatait konszolidáltuk.

Az egyedi banki változókat $\left(Y^{j}\right)$ a következőképpen határoztuk meg.

A nem pénzügyi magánszektornak nyújtott hitelek és a tőlük származó betétek hányadosának százszorosa jelenti a hitel/betét mutatót (LOAN TO DEPOSIT).

A mérlegföösszeg-arányos devizacsere-állomány (FX swAP) esetében a nettó forinttal szembeni devizacsere-állományt osztottuk az összes eszközzel, és a hányados százszorosát vettük.

A mérlegföösszeg-arányos likvideszköz-állomány (LIQUID ASSET) esetében hasonlóan jártunk el. A számlálóként használt likvideszköz-állomány tartalmazza a pénztárt, elszámolási számlákat, állampapírokat, jegybanki kötvényeket és betéteket.

A tőkemegfelelési mutató (CAPITAL ADEQUACY) a felügyeleti felülvizsgálati és értékelési folyamat (supervisory review and evaluation process SREP) után figyelembe veszi, hogy a 2. pillér alatt elvégzett vizsgálat lényegesen módosíthatja mind a figyelembe vehető tőkét, mind a tőkekövetelményt, így rendszerint alacsonyabb tőkemegfelelési mutatót kapunk. Ez az információ azért fontos, mert a bankoknak ténylegesen a SREP után elvárt szintnek kell megfelelniük.

Az NPL-arány számításában a nem teljesítő hiteleket a kockázati besorolás alapján határoztuk meg, vagyis a rossz, kétes és átlag alatti kategóriákba tartozó hiteleket tekintettük nem teljesítőnek. Ezt osztottuk el a teljes hitelállománnyal és szoroztuk be százzal. Bár rendszerint a 90 napnál régebben nem teljesítő hiteleket szokás nem teljesítőnek tekinteni, azért használtunk más definíciót, mert így az egész megfigyelési időszakra rendelkezésre áll az adat. A két mutató nagyon szorosan együtt mozog, ezért ez nem okoz problémát. A méret (тотAL ASSETS) változó esetében az összes eszköz logaritmusát használtuk. Minden bankspecifikus változó a Magyar Nemzeti Bank adatbázisából származik.

A modellekben a következő változókat $\left(Y^{j, g}\right)$ használtuk a tulajdonos csoportok jellemzésére:

- a LOAN TO DEPOSIT (hitel/betét mutatót) az anyabankok esetében is ugyanúgy definiáltuk, mint a leánybankoknál;

- a CAPITAL ADEQUACY (tőkemegfelelési mutató) esetében hivatalos adat nem áll rendelkezésre a 2. pilléres felülvizsgálat hatásáról, így ezt nem vesszük figyelembe a mutatóban, csak a 1. pilléres mutatót;

- a LEVERAGE RATIO (tőkeáttétel) mutatót a mérlegföösszeg és a tőke hányadosaként definiáltuk, vagyis a magasabb érték jelent nagyobb kockázatot;

- a ROA esetében az adózás utáni eredményt osztottuk el az összes eszközzel. A tulajdonos csoportok adatait a Bankscope-ból gyüjtöttük össze, illetve esetenként kiegészítettük az éves jelentések alapján. A Budapest Bankot, illetve anyabankját kihagytuk ezen specifikácókból, mert a tulajdonos GE speciális helyzete miatt az adatok többsége nem állt rendelkezésre.

A makrováltozókat tartalmazó $M$ vektor a hazai gazdasági környezetet, illetve a keresleti oldalt jellemzi. A következő mutatókat vettük figyelembe: 
- a GDP GROWTH mutatót, azaz a GDP éves növekedését a nominális bruttó nemzeti össztermék növekedési ütemeként határoztuk meg; ${ }^{8}$

- a HUF/EUR árfolyamot ugyancsak szerepeltettük a változók között;

- a BubOR 3 MONTH mutató, a 3 hónapos Bubor, a bankközi piaci kamat éves átlagaként került be;

- a HOUSEHOLD CONFIDENCE mutatót, az Eurostat által publikált fogyasztói bizalmi indikátort vettük még figyelembe. Az előbbiek esetében az adatok forrása az MNB volt, illetve a GDP esetében KSH-adatokat használtunk (lásd az F1. táblázatot).

\section{Az eredmények elemzése}

Az eredményeinket az 1-6. táblázatok foglalják össze. Elsőként a banki változók hatását elemezzük (1. táblázat), majd a makrokörnyezetre is kontrollálunk (2. táblázat). Másodszor, hasonló módon elemezzük az anyabanki tulajdonságok hatását (3. és 4 . táblázat). Végül az 6. táblázat mutatja be a válság hatását.

\section{Az egyedi banki változók hatása}

A 1. táblázat a banki tulajdonságok éves hiteldinamikára gyakorolt hatását tartalmazza [(2) egyenlet]. ${ }^{9}$

Az 2. táblázat a banki tulajdonságok és a makrokörnyezet éves hiteldinamikára gyakorolt hatását tartalmazza [(2) egyenlet].

Az eredményeink megerősítik, hogy a magasabb finanszírozási kockázat szignifikáns negatív hatással van a hitelezési aktivitásra. A hitel/betét (LOAN TO DEPOSIT) mutató (vagyis a finanszírozási kockázat) hatása szignifikáns és negatív a hitelállomány-növekedésre (CREDIT GROWTH). Egy százalékponttal magasabb hitel/betét mutató 0,08 százalékponttal alacsonyabb hitelállomány-növekedéssel jár. Figyelembe véve, hogy a hitel/betét mutató Magyarországon rendszerint jócskán meghaladta a 100 százalékot (a minta mediánja 133), és a növekedési ütem mediánja pedig 18,8 százalék volt, ez a hatás relevánsnak tekinthető közgazdasági értelemben is (lásd F2. táblázat). Az eredmény azt is igazolja, hogy a külföldi szereplők által dominált bankrendszerben is fontosak a belső megtakarítások. Vagyis az Aydin [2008] által bemutatott hatás, amely szerint a könnyü hozzáférés a külső forrásokhoz segíti a hitelezést, ezen a mintán nem bizonyult relevánsnak. Természetesen ennek oka lehet, hogy a szerző a rendszerváltást követő időszakra fókuszált, és több országot együtt vizsgált.

\footnotetext{
${ }^{8}$ Mivel nominális hitelállomány-változást magyarázunk, így indokoltnak tartottuk a nominális GDP-növekedést szerepeltetni.

${ }^{9} \mathrm{Az}$ 1-6. táblázatban a függő változó (CREDIT GROWTH) a banki hitelállomány éves százalékpontos változása (vagyis az éves eltérés a hitelállományok természetes logaritmusa között 100-zal szorozva). A becsült együtthatók így azt mutatják, hány százalékponttal változik a hitelállomány növekedési üteme a magyarázó változó 1 egységnyi elmozdulására.
} 
1. táblázat

Az egyedi banki tulajdonságokat tartalmazó modellspecifikációk

Függő változó: a banki hitelállomány éves százalékpontos változása

\begin{tabular}{|c|c|c|c|c|c|c|}
\hline & (1) & (2) & (3) & (4) & (5) & (6) \\
\hline $\begin{array}{l}\text { LOAN TO DEPOSIT, } \\
\text { Q-4 }\end{array}$ & $\begin{array}{l}-0,059 \\
(0,014)^{* * *}\end{array}$ & $\begin{array}{l}-0,060 \\
+(0,015)^{* * *}\end{array}$ & $\begin{array}{l}-0,081 \\
+(0,016)^{* * *}\end{array}$ & $\begin{array}{l}-0,081 \\
+(0,016)^{* * *}\end{array}$ & $\begin{array}{l}-0,082 \\
(0,016)^{* * *}\end{array}$ & $\begin{array}{l}-0,084 \\
+(0,017)^{\star * *}\end{array}$ \\
\hline FX sWAP, Q-4 & & $\begin{array}{l}-0,037 \\
(0,069)\end{array}$ & $\begin{array}{l}-0,143 \\
(0,077)^{*}\end{array}$ & $\begin{array}{l}-0,144 \\
(0,076)^{*}\end{array}$ & $\begin{array}{l}-0,141 \\
(0,077)^{*}\end{array}$ & $\begin{array}{c}-0,061 \\
(0,078)\end{array}$ \\
\hline LIQUID ASSETS, Q-4 & & & $\begin{array}{l}-0,273 \\
(0,080)^{\star * *}\end{array}$ & $\begin{array}{l}-0,275 \\
+(0,080)^{* * *}\end{array}$ & $\begin{array}{l}-0,299 \\
(0,082)^{* * *}\end{array}$ & $\begin{array}{l}-0,256 \\
+(0,085)^{* * *}\end{array}$ \\
\hline $\begin{array}{l}\text { CAPITAL ADEQUACY, } \\
\text { Q-4 }\end{array}$ & & & & $\begin{array}{c}0,028 \\
(0,236)\end{array}$ & $\begin{array}{c}0,028 \\
(0,234)\end{array}$ & $\begin{array}{l}-0,221 \\
(0,233)\end{array}$ \\
\hline NPL, Q-4 & & & & & $\begin{array}{c}0,156 \\
(0,096)\end{array}$ & $\begin{array}{c}0,093 \\
(0,100)\end{array}$ \\
\hline $\begin{array}{l}\text { LOG TOTAL ASSET, } \\
\text { Q-4 }\end{array}$ & & & & & & $\begin{array}{l}-2,598 \\
(0,726)^{* * *}\end{array}$ \\
\hline $\begin{array}{l}\text { MERGER, } \\
\text { KÉTÉRTÉKÜ }\end{array}$ & $\begin{array}{l}47,244 \\
(7,517)^{\star * *}\end{array}$ & $\begin{array}{l}47,467 \\
+(7,518)^{* * *}\end{array}$ & $\begin{array}{l}48,130 \\
+(7,586)^{* * *}\end{array}$ & $\begin{array}{l}48,212 \\
+(7,591)^{* * *}\end{array}$ & $\begin{array}{l}48,248 \\
(7,583)^{* * *}\end{array}$ & $\begin{array}{l}47,802 \\
*(7,070)^{* * *}\end{array}$ \\
\hline $\begin{array}{l}\text { CRISIS, } \\
\text { KÉTÉRTÉKÜ }\end{array}$ & $\begin{array}{l}-28,366 \\
(1,068)^{\star * *}\end{array}$ & $\begin{array}{l}-28,297 \\
(1,069)^{* * *}\end{array}$ & $\begin{array}{l}-26,764 \\
(1,214)^{* * *}\end{array}$ & $\begin{array}{l}-26,760 \\
(1,205)^{* * *}\end{array}$ & $\begin{array}{l}-27,922 \\
+(1,314)^{* * *}\end{array}$ & $\begin{array}{l}-25,550 \\
(1,315)^{\star * *}\end{array}$ \\
\hline $\begin{array}{l}\text { TRANSITION, } \\
\text { KÉTÉRTÉKÜ }\end{array}$ & $\begin{array}{l}-0,632 \\
(1,826)\end{array}$ & $\begin{array}{l}-0,919 \\
(1,942)\end{array}$ & $\begin{array}{l}-0,415 \\
(1,920)\end{array}$ & $\begin{array}{c}-0,415 \\
(1,922)\end{array}$ & $\begin{array}{c}-0,519 \\
(1,921)\end{array}$ & $\begin{array}{l}-2,219 \\
(2,044)\end{array}$ \\
\hline $\begin{array}{l}\text { PARENT, } \\
\text { KÉTÉRTÉKÜ }\end{array}$ & $\begin{array}{l}4,246 \\
(1,391)^{\star * *}\end{array}$ & $\begin{array}{l}4,253 \\
+(1,395)^{* * *}\end{array}$ & $\begin{array}{c}4,110 \\
+(1,444)^{* * *}\end{array}$ & $\begin{array}{c}4,192 \\
+(1,696)^{* *}\end{array}$ & $\begin{array}{l}4,010 \\
(1,717)^{\star *}\end{array}$ & $\begin{array}{c}-0,363 \\
(1,910)\end{array}$ \\
\hline EARLYREPAYMENT & $\begin{array}{l}-5,336 \\
(1,048)^{* * *}\end{array}$ & $\begin{array}{l}-5,291 \\
+(1,057)^{* * *}\end{array}$ & $\begin{array}{l}-4,799 \\
+(1,022)^{* * *}\end{array}$ & $\begin{array}{l}-4,758 \\
+(1,073)^{* * *}\end{array}$ & $\begin{array}{l}-5,370 \\
+(1,147)^{* * *}\end{array}$ & $\begin{array}{l}-5,645 \\
+(1,058)^{\star * *}\end{array}$ \\
\hline Konstans & $\begin{array}{l}30,185 \\
(1,829)^{\star * *}\end{array}$ & $\begin{array}{l}30,612 \\
+(2,127)^{* * *}\end{array}$ & $\begin{array}{l}38,412 \\
+(3,075)^{* * *}\end{array}$ & $\begin{array}{l}38,118 \\
(4,080)^{* * *}\end{array}$ & $\begin{array}{l}38,155 \\
(4,052)^{* * *}\end{array}$ & $\begin{array}{c}79,498 \\
+(11,508)^{* * *}\end{array}$ \\
\hline$R^{2}$ & 0,63 & 0,63 & 0,64 & 0,64 & 0,64 & 0,65 \\
\hline$N$ & 578 & 578 & 578 & 578 & 578 & 578 \\
\hline
\end{tabular}

Megjegyzés: zárójelben a robusztus standard hibák.

* 10 százalékos, ${ }^{\star *} 5$ százalékos ${ }^{* * *} 1$ százalékos szignifikanciaszintet jelent.

A likvid eszközök mérlegföösszeg-arányos állománya (LIQUID ASSET) ugyancsak szignifikáns az összes specifikációban, és negatív az előjele. Ez arra utal, hogy a mutató a kockázatvállalási hajlandóságot fogja meg, éppen ezért az alacsonyabb mutató magasabb aktivitással jár együtt. A koefficiens nagysága 0,23 és 0,26 között mozog a különböző specifikációknál (1. táblázat), ami közgazdaságilag is releváns (az F2. táblázatban szereplő mediánérték 17,28), bár kisebb a hatása, mint a hitel/betét mutatóé. A fentiek mellett az eredményt az is magyarázhatja, hogy ennél a mutatónál viszonylag kicsi a keresztmetszeti variancia. Ahogy Banai és szerzőtársai [2010b] bemutatják, a válság előtt a teljes bankrendszer folyamatosan csökkentette a likviditási pufferét, majd a Lehman-csőd után elkezdte visszaépíteni azt. 
2. táblázat

A banki tulajdonságokat és a makrokörnyezet hatásait tartalmazó modellspecifikációk

Függő változó: a banki hitelállomány éves százalékpontos változása

\begin{tabular}{|c|c|c|}
\hline & (1) & $(2)$ \\
\hline LOAN TO DEPOSIT, Q-4 & $\begin{array}{l}-0,081 \\
(0,018)^{\star \star \star}\end{array}$ & $\begin{array}{l}-0,082 \\
(0,017)^{\star * *}\end{array}$ \\
\hline FX sWAP, Q-4 & $\begin{array}{l}-0,145 \\
(0,082)^{\star}\end{array}$ & $\begin{array}{c}-0,071 \\
(0,079)\end{array}$ \\
\hline LIQUID ASSET, Q-4 & $\begin{array}{l}-0,229 \\
(0,092)^{\star *}\end{array}$ & $\begin{array}{l}-0,254 \\
(0,086)^{* * *}\end{array}$ \\
\hline CAPITAL ADEQUACY, Q-4 & $\begin{array}{c}-0,044 \\
(0,242)\end{array}$ & $\begin{array}{c}-0,175 \\
(0,236)\end{array}$ \\
\hline NPL, Q-4 & $\begin{array}{l}0,516 \\
(0,163)^{\star \star \star}\end{array}$ & $\begin{array}{c}0,114 \\
(0,119)\end{array}$ \\
\hline LOG TOTAL ASSETS, Q-4 & $\begin{array}{l}-1,963 \\
(0,658)^{* * *}\end{array}$ & $\begin{array}{l}-2,105 \\
(0,720)^{* * *}\end{array}$ \\
\hline GDP GROWTH & & $\begin{array}{c}0,369 \\
(0,287)\end{array}$ \\
\hline HUF/EUR & & $\begin{array}{c}0,048 \\
(0,048)\end{array}$ \\
\hline BUBOR 3 MONTH & & $\begin{array}{l}0,875 \\
(0,398)^{\star *}\end{array}$ \\
\hline HOUSEHOLD CONFIDENCE & & $\begin{array}{c}0,061 \\
(0,072)\end{array}$ \\
\hline CRISIS, KÉTÉRTÉKÜ & & $\begin{array}{l}-23,992 \\
(2,696)^{\star * *}\end{array}$ \\
\hline TRANSITION, KÉTÉRTÉKÜ & & $\begin{array}{l}-6,973 \\
(3,337)^{\star *}\end{array}$ \\
\hline EARLYREPAYMENT & & $\begin{array}{l}-6,386 \\
(1,188)^{* * *}\end{array}$ \\
\hline MERGER, KÉTÉRTÉKÜ & $\begin{array}{l}48,488 \\
(6,121)^{\star * *}\end{array}$ & $\begin{array}{l}47,463 \\
(6,735)^{* * *}\end{array}$ \\
\hline PARENT, KÉTÉRTÉKÜ & $\begin{array}{c}0,202 \\
(2,054)\end{array}$ & $\begin{array}{c}0,448 \\
(1,934)\end{array}$ \\
\hline Time fiXed effect & igen & \\
\hline Konstans & $\begin{array}{l}60,668 \\
(11,475)^{\star * \star}\end{array}$ & $\begin{array}{c}48,916 \\
(19,260)^{\star *}\end{array}$ \\
\hline$R^{2}$ & 0,69 & 0,65 \\
\hline$N$ & 578 & 578 \\
\hline
\end{tabular}

Megjegyzés: a zárójelben a robusztus standard hibák szerepelnek.

${ }^{\star * *} 1$ százalékos, ${ }^{* *} 5$ százalékos, ${ }^{\star} 10$ százalékos szinten szignifikáns. 
A devizacsere-piacra való ráutaltságból (FX sWAP) származó likviditási kockázat hatását ugyancsak teszteltük. Az eredményeink, bár nem voltak minden specifikációban szignifikánsak, de alátámasztották a feltételezésünket. A negatív előjel megerősíti, hogy a devizacsere-piacra való ráutaltság kockázatot jelent, és fékezi a hitelezési aktivitást.

Összhangban a korábbi tanulmányokkal (Aydin [2008], Everaert és szerzőtársai [2015], Temesváry-Banai [2015]) a bankméret (TотAL AssETs) hatása a hitelezésre egyértelműen negatív. Ennek egyszerü, technikai magyarázata van. Nominálisan azonos nettó kibocsátás egy kisebb bank esetében nagyobb növekedési ütemet jelent. A megfigyelési időszak folyamán a bankok mérete radikálisan megnőtt, mivel a minta eleje visszanyúlik a bankrendszeri átalakulás végéhez. Fontos továbbá, hogy a legjelentősebb magyarországi bankokat tartalmazza a mintánk. A piaci erőben így többségüknél nincs lényeges különbség. ${ }^{10}$

A válság (CRISIs) a magyar bankrendszer hitelezési politikáját is jelentős mértékben megváltoztatta. A 2. ábra bemutatta, hogy rendszerszinten a válság fordulópontot jelentett a hitelezési aktivitásban. Ezt erősíti meg a modellünk is, hiszen a válság hatása negatív, közgazdaságilag és statisztikailag egyaránt szignifikáns. Ez összhangban van a releváns szakirodalommal (De Haas és szerzötársai [2012], Temesváry-Banai [2015], Everaert és szerzőtársai [2015]). Az eredmény nem meglepö, de fontos hangsúlyozni, hogy az igen erős hatás érvényesülését akkor is kimutattuk, amikor a banki müködést jellemzö változókat vettük figyelembe. Vagyis nem csak ezeken keresztül volt hatása a válságnak a hitelezésre. Az eredményeink a tulajdonosi struktúrával kapcsolatos feltételezésünket viszont nem támasztják alá. A külföldi tulajdonos nincs szignifikáns hatással a bank hitelezési aktivitására. A szakirodalom sem egyértelmü ebben a kérdésben. A szerzők egy része (Banai és szerzőtársai [2010a]) a külföldi tulajdonosok támogató hatását emelik ki, míg mások inkább a potenciális fertőzés veszélyét hangsúlyozzák a külföldi tulajdonban levő bankoknál (például De Haas és szerzőtársai [2012], Giannetti-Laeven [2012]). Az eredményeink azt mutatják, hogy önmagában a tulajdonosi struktúra nem határozza meg a hitelezési aktivitást. A becslési eredményünket némiképp gyengíti, hogy csak két releváns hazai tulajdonú bankot lehetett figyelembe venni.

\section{A tulajdonos bankcsoport helyzetének szerepe}

Megállapítottuk, hogy a tulajdonosi szerkezet önmagában nem releváns a hitelezési aktivitás szempontjából. Következő lépésként kiegészítettük a becslésünket az anyaintézmények tulajdonságaival [mérlegföösszeg-arányos nyereség (ROA), a nem teljesítő hitelek állományon belül aránya (NPL), a tőkemegfelelési mutató (CAPITAL ADEQUACY) és a tökeáttétel (LEVERAGe Ratio)]. Arra kerestük a választ, hogy az

${ }^{10}$ A fenti megállapításoknál az oksági viszony több esetben akár fordítottan is igaz lehet. Például a hitelezési aktivitás hatással lehet a jövedelmezőségre vagy a likviditási helyzetre is. Jelen vizsgálatunknak azonban nem célja, hogy a fordított irány érvényességét is vizsgálja. Ez további kutatási irány lehet. 
anyabankoknak meghatározó szerepük van-e a külföldi tulajdonban levő bankok hitelezésében. Becslésünk eredményeit a 3. és 4. táblázat foglalja össze.

A 3. táblázat a banki és az anyabanki tulajdonságok éves hiteldinamikára gyakorolt hatását tartalmazza [(4) egyenlet].

\section{3. táblázat}

A banki és az anyabanki tulajdonságok hatásait tartalmazó modellspecifikációk

Függő változó: a banki hitelállomány éves százalékpontos változása

\begin{tabular}{|c|c|c|c|c|}
\hline & (1) & (2) & (3) & (4) \\
\hline LOAN TO DEPOSIT, Q-4 & $\begin{array}{l}-0,110 \\
(0,022)^{* * *}\end{array}$ & $\begin{array}{l}-0,113 \\
(0,021)^{\star * *}\end{array}$ & $\begin{array}{l}-0,114 \\
(0,021)^{* * *}\end{array}$ & $\begin{array}{l}-0,115 \\
(0,021)^{\star * *}\end{array}$ \\
\hline FX sWAP, Q-4 & $\begin{array}{l}-0,064 \\
(0,093)\end{array}$ & $\begin{array}{l}-0,084 \\
(0,103)\end{array}$ & $\begin{array}{l}-0,043 \\
(0,109)\end{array}$ & $\begin{array}{c}0,004 \\
(0,111)\end{array}$ \\
\hline LIQUID ASSET, Q-4 & $\begin{array}{l}-0,329 \\
(0,090)^{* * *}\end{array}$ & $\begin{array}{l}-0,317 \\
(0,097)^{\star * *}\end{array}$ & $\begin{array}{l}-0,330 \\
(0,097)^{\star * *}\end{array}$ & $\begin{array}{l}-0,342 \\
(0,098)^{\star * *}\end{array}$ \\
\hline CAPITAL ADEQUACY, Q-4 & $\begin{array}{l}-0,748 \\
(0,332)^{\star *}\end{array}$ & $\begin{array}{l}-0,727 \\
(0,337)^{\star *}\end{array}$ & $\begin{array}{l}-0,741 \\
(0,335)^{\star *}\end{array}$ & $\begin{array}{l}-0,663 \\
(0,332)^{\star *}\end{array}$ \\
\hline NPL, Q-4 & $\begin{array}{l}-0,032 \\
(0,107)\end{array}$ & $\begin{array}{c}0,005 \\
(0,130)\end{array}$ & $\begin{array}{c}0,054 \\
(0,139)\end{array}$ & $\begin{array}{c}0,050 \\
(0,139)\end{array}$ \\
\hline LOG TOTAL ASSETS, Q-4 & $\begin{array}{l}-5,045 \\
(0,977)^{\star * *}\end{array}$ & $\begin{array}{l}-5,042 \\
(0,974)^{\star * *}\end{array}$ & $\begin{array}{l}-4,773 \\
(0,963)^{\star * *}\end{array}$ & $\begin{array}{l}-4,678 \\
(0,967)^{\star * *}\end{array}$ \\
\hline $\begin{array}{l}\text { LOAN TO DEPOSIT } \times \text { PARENT } \\
\text { GROUP, Q- } 4\end{array}$ & $\begin{array}{l}-0,027 \\
(0,008)^{* * *}\end{array}$ & $\begin{array}{l}-0,028 \\
(0,008)^{* * *}\end{array}$ & $\begin{array}{l}-0,033 \\
(0,009)^{\star * *}\end{array}$ & $\begin{array}{l}-0,027 \\
(0,010)^{* * *}\end{array}$ \\
\hline $\begin{array}{l}\text { CAPITAL ADEQUACY } \times \text { PARENT } \\
\text { GROUP, Q-4 }\end{array}$ & & $\begin{array}{l}-0,314 \\
(0,603)\end{array}$ & $\begin{array}{l}-0,475 \\
(0,650)\end{array}$ & $\begin{array}{l}-0,376 \\
(0,644)\end{array}$ \\
\hline $\begin{array}{l}\text { LEVERAGE } \times \text { PARENT GROUP, } \\
\mathrm{Q}-4\end{array}$ & & & $\begin{array}{c}-0,716 \\
(0,469)\end{array}$ & $\begin{array}{l}-1,433 \\
(0,457)^{\star * *}\end{array}$ \\
\hline ROA $\times$ PARENT, $\mathrm{Q}-4$ & & & & $\begin{array}{l}4,419 \\
(1,292)^{\star * *}\end{array}$ \\
\hline EARLYREPAYMENT & $\begin{array}{l}-6,284 \\
(1,336)^{* * *}\end{array}$ & $\begin{array}{l}-6,070 \\
(1,389)^{* * *}\end{array}$ & $\begin{array}{l}-6,081 \\
(1,379)^{\star * *}\end{array}$ & $\begin{array}{l}-5,706 \\
(1,365)^{\star * *}\end{array}$ \\
\hline MERGER, KÉTÉRTÉKÜ & $\begin{array}{l}48,283 \\
(6,825)^{\star * *}\end{array}$ & $\begin{array}{l}48,027 \\
(6,902)^{\star * *}\end{array}$ & $\begin{array}{l}48,552 \\
(6,602)^{\star * *}\end{array}$ & $\begin{array}{l}48,764 \\
(6,591)^{\star * *}\end{array}$ \\
\hline CRISIS, KÉTÉRTÉKÜ & $\begin{array}{l}-20,982 \\
\quad(1,721)^{\star * *}\end{array}$ & $\begin{array}{l}-20,681 \\
\quad(1,720)^{\star * *}\end{array}$ & $\begin{array}{l}-20,288 \\
\quad(1,791)^{\star * *}\end{array}$ & $\begin{array}{l}-17,798 \\
\quad(1,933)^{\star * *}\end{array}$ \\
\hline TRANSITION, KÉTÉRTÉKÜ & $\begin{array}{c}-1,881 \\
(2,480)\end{array}$ & $\begin{array}{c}-2,244 \\
(2,815)\end{array}$ & $\begin{array}{c}-2,359 \\
(2,836)\end{array}$ & $\begin{array}{c}-1,879 \\
(2,842)\end{array}$ \\
\hline Konstans & $\begin{array}{l}127,249 \\
(15,296)^{\star * *}\end{array}$ & $\begin{array}{l}130,804 \\
(16,069)^{\star * *}\end{array}$ & $\begin{array}{l}132,822 \\
(16,444)^{\star * *}\end{array}$ & $\begin{array}{l}129,123 \\
(16,741)^{\star * *}\end{array}$ \\
\hline$R^{2}$ & 0,67 & 0,67 & 0,67 & 0,67 \\
\hline$N$ & 436 & 436 & 436 & 436 \\
\hline
\end{tabular}

Megjegyzés: a zárójelben a robusztus standard hibák szerepelnek.

${ }^{* * *} 1$ százalékos, ${ }^{* *} 5$ százalékos, ${ }^{*} 10$ százalékos szinten szignifikáns. 
A 4. táblázat a banki, az anyabanki tulajdonságok és a makrokörnyezet éves hiteldinamikára gyakorolt hatását tartalmazza [(5) egyenlet].

4. táblázat

A banki, az anyabanki tulajdonságokat és a makrováltozókat tartalmazó modellspecifikációk Függő változó: a banki hitelállomány éves százalékpontos változása

\begin{tabular}{|c|c|c|}
\hline & (1) & (2) \\
\hline LOAN TO DEPOSIT, Q-4 & $\begin{array}{l}-0,126 \\
(0,020)^{* * *}\end{array}$ & $\begin{array}{l}-0,117 \\
(0,021)^{\star * *}\end{array}$ \\
\hline FX sWAP, Q-4 & $\begin{array}{l}-0,254 \\
(0,127)^{\star \star}\end{array}$ & $\begin{array}{c}-0,047 \\
(0,114)\end{array}$ \\
\hline LIQUID ASSET, Q-4 & $\begin{array}{l}-0,314 \\
(0,101)^{* * *}\end{array}$ & $\begin{array}{l}-0,345 \\
(0,097)^{\star * *}\end{array}$ \\
\hline CAPITAL ADEQUACY, Q-4 & $\begin{array}{l}-0,547 \\
(0,328)^{*}\end{array}$ & $\begin{array}{c}-0,508 \\
(0,340)\end{array}$ \\
\hline NPL, Q-4 & $\begin{array}{l}0,454 \\
(0,181)^{\star *}\end{array}$ & $\begin{array}{c}0,135 \\
(0,147)\end{array}$ \\
\hline LOG TOTAL ASSETS, Q-4 & $\begin{array}{l}-4,273 \\
(0,933)^{\star * *}\end{array}$ & $\begin{array}{l}-3,749 \\
(1,001)^{\star * *}\end{array}$ \\
\hline LOAN TO DEPOSIT $\times$ PARENT, Q-4 & $\begin{array}{l}-0,029 \\
(0,011)^{* * *}\end{array}$ & $\begin{array}{l}-0,018 \\
(0,011)^{*}\end{array}$ \\
\hline CAPITAL ADEQUACY $\times$ PARENT, Q-4 & $\begin{array}{c}-0,563 \\
(0,708)\end{array}$ & $\begin{array}{c}-0,159 \\
(0,670)\end{array}$ \\
\hline LEVERAGE $\times$ PARENT, Q-4 & $\begin{array}{c}-0,439 \\
(0,486)\end{array}$ & $\begin{array}{l}-1,187 \\
(0,472)^{* *}\end{array}$ \\
\hline ROA $\times$ PARENT, $\mathrm{Q}-4$ & $\begin{array}{c}0,441 \\
(1,321)\end{array}$ & $\begin{array}{l}4,577 \\
(1,303)^{\star * *}\end{array}$ \\
\hline MERGER, KÉTÉRTÉKÜ & $\begin{array}{l}46,604 \\
(5,733)^{* * *}\end{array}$ & $\begin{array}{l}48,405 \\
(6,295)^{* * *}\end{array}$ \\
\hline GDP GROWTH & & $\begin{array}{c}0,231 \\
(0,337)\end{array}$ \\
\hline HUF/EUR & & $\begin{array}{c}0,008 \\
(0,054)\end{array}$ \\
\hline BUBOR 3 MONTH & & $\begin{array}{l}1,198 \\
(0,475)^{\star *}\end{array}$ \\
\hline HOUSEHOLD CONFIDENCE & & $\begin{array}{c}0,048 \\
(0,082)\end{array}$ \\
\hline CRISIS, KÉTÉRTÉKÜ & & $\begin{array}{l}-16,744 \\
(3,373)^{\star * *}\end{array}$ \\
\hline TRANSITION, KÉTÉRTÉKÜ & & $\begin{array}{c}-6,153 \\
(4,093)\end{array}$ \\
\hline EARLYREPAYMENT & & $\begin{array}{l}-6,056 \\
(1,448)^{\star * *}\end{array}$ \\
\hline
\end{tabular}


A 4. táblázat folytatása

Time FIXED EFFECT

igen

Konstans

123,690

96,446

$R^{2}$

$(19,213)^{* * *}$

$(26,190)^{* * *}$

0,74

0,68

N

436

436

Megjegyzés: a zárójelben a robusztus standard hibák szerepelnek.

${ }^{* * *} 1$ százalékos, ${ }^{* *} 5$ százalékos, ${ }^{\star} 10$ százalékos szinten szignifikáns.

Az első megállapításunk, hogy a tulajdonos intézmény finanszírozási kockázata szignifikáns negatív hatással van a leánybank hitelezésére. Vagyis a stabilabb finanszírozási pozícióban levő bankcsoport magyarországi leánybankja aktívabb, mint a kevésbé stabil tulajdonossal rendelkező versenytársai. Az együttható nagysága azonban lényegesen kisebb, mint a leánybank saját hitel/betét mutatója (LOAN TO DEPOSIT) esetén volt. Ez az eredmény hasonló Cetorelli-Goldberg [2011], illetve Giannetti-Laeven [2012] megállapításához, amely szerint az anyabank likviditási problémája negatív hatással van a leánybank tevékenységére is. Fontos hangsúlyoznunk, hogy ez nem azt jelenti, hogy a rosszabb helyzetü csoportok a válság esetén azonnal kivonják a leánybankjaikból a forrást, inkább arra utal, hogy intenzívebb mérlegkiigazításba kezdenek hiteloldalon.

A tulajdonos bank tőkeellátottsága és a leánybank aktivitása között is szignifikáns kapcsolatot találtunk. Egy százalékponttal alacsonyabb tőkeáttétel az anyabanknál 1,4 százalékponttal nagyobb hitelállomány-növekedési ütemmel jár együtt a leánybanknál. Az eredmény intuitív, hiszen a tőkével ellátott csoportoknak van lehetőségük támogatni a leányok tevékenységét. Végül, a várakozásunkkal összhangban a jövedelmezőbb anyabankok leányai is aktívabbak a fogadó országban. Ennek két oka van: a magasabb jövedelmezőség javítja a hitelezési képességet (a tőkén keresztül), illetve a várt megtérülés is nagyobb lehet e csoportokban, ami ugyancsak serkenti az aktivitást.

Az anyabanki tulajdonságokat tartalmazó specifikációban az egyedi banki jellemzők hatását is újrabecsültük. Ez megerősítette a korábbi eredményeinket. Mind a likviditási mutatók, mind a méret szignifikánsnak bizonyult a korábbival megegyező előjellel. Az egyetlen eltérés, hogy az egyik specifikációban a tőkemegfelelési mutató szignifikáns lett, és az előjele meglepő módon negatív volt. Ennek magyarázata, hogy a külföldi tulajdonban levő bankok tőkemenedzsmentje gyakran eltér a helyi bankokétól. Néhányuk mindig a minimális szinten tartja a tőkemegfelelési mutatót, míg mások jelentős puffert képeznek. Éppen ezért ezeknél a bankoknál a tőkehelyzet a hitelezési politikával kapcsolatos döntésekben nem mindig meghatározó (Temesváry [2014b]).

A legfőbb specifikációkat Newey-West-féle becsléssel is újraszámoltuk, hogy az esetleges autokorrelációt így kiszürjük. Ahogy az 5. táblázat - amely a banki, az anyabanki tulajdonságok és a makrokörnyezet éves hiteldinamikára gyakorolt hatását tartalmazza - mutatja, ezek a becslések megerősítik a korábbi eredményeinket. 
5. táblázat

A főbb modellspecifikációk becslése Newey-West-féle standard hibákkal

Függő változó: a banki hitelállomány éves százalékpontos változása

\begin{tabular}{|c|c|c|c|}
\hline & (1) & (2) & (3) \\
\hline LOAN TO DEPOSIT, Q-4 & $\begin{array}{l}-0,084 \\
(0,025)^{* * *}\end{array}$ & $\begin{array}{l}-0,082 \\
(0,026)^{* * *}\end{array}$ & $\begin{array}{l}-0,115 \\
(0,029)^{\star * *}\end{array}$ \\
\hline FX SWAP, Q-4 & $\begin{array}{c}-0,061 \\
(0,102)\end{array}$ & $\begin{array}{c}-0,071 \\
(0,104)\end{array}$ & $\begin{array}{c}0,004 \\
(0,137)\end{array}$ \\
\hline LIQUID ASSET, Q-4 & $\begin{array}{l}-0,256 \\
(0,139)^{*}\end{array}$ & $\begin{array}{l}-0,254 \\
(0,141)^{*}\end{array}$ & $\begin{array}{l}-0,342 \\
(0,151)^{\star *}\end{array}$ \\
\hline CAPITAL ADEQUACY, Q-4 & $\begin{array}{l}-0,221 \\
(0,354)\end{array}$ & $\begin{array}{c}-0,175 \\
(0,358)\end{array}$ & $\begin{array}{c}-0,663 \\
(0,517)\end{array}$ \\
\hline NPL, Q-4 & $\begin{array}{c}0,093 \\
(0,172)\end{array}$ & $\begin{array}{c}0,114 \\
(0,196)\end{array}$ & $\begin{array}{c}0,050 \\
(0,215)\end{array}$ \\
\hline LOG TOTAL ASSETS, Q-4 & $\begin{array}{l}-2,598 \\
(1,175)^{* *}\end{array}$ & $\begin{array}{l}-2,105 \\
(1,194)^{*}\end{array}$ & $\begin{array}{l}-4,678 \\
(1,461)^{* * *}\end{array}$ \\
\hline PARENT, KÉTÉRTÉKÜ & $\begin{array}{c}-0,363 \\
(3,032)\end{array}$ & $\begin{array}{c}0,448 \\
(3,083)\end{array}$ & \\
\hline MERGER, KÉTÉRTÉKÜ & $\begin{array}{l}47,802 \\
(11,674)^{\star * *}\end{array}$ & $\begin{array}{l}47,463 \\
(11,080)^{\star * *}\end{array}$ & $\begin{array}{c}48,764 \\
(11,190)^{* * *}\end{array}$ \\
\hline CRISIS, KÉTÉRTÉKÜ & $\begin{array}{l}-25,550 \\
(2,147)^{\star * *}\end{array}$ & $\begin{array}{l}-23,992 \\
(3,840)^{\star * *}\end{array}$ & $\begin{array}{l}-17,798 \\
(3,018)^{* * *}\end{array}$ \\
\hline TRANSITION, KÉTÉRTÉKÜ & $\begin{array}{c}-2,219 \\
(3,136)\end{array}$ & $\begin{array}{c}-6,973 \\
(4,558)\end{array}$ & $\begin{array}{c}-1,879 \\
(3,913)\end{array}$ \\
\hline EARLYREPAYMENT & $\begin{array}{l}-5,645 \\
(1,577)^{\star * *}\end{array}$ & $\begin{array}{l}-6,386 \\
(1,720)^{\star * *}\end{array}$ & $\begin{array}{l}-5,706 \\
(2,035)^{* * *}\end{array}$ \\
\hline GDP GROWTH & & $\begin{array}{c}0,369 \\
(0,371)\end{array}$ & \\
\hline HUF/EUR & & $\begin{array}{c}0,048 \\
(0,060)\end{array}$ & \\
\hline BUBOR 3 MONTH & & $\begin{array}{c}0,875 \\
(0,580)\end{array}$ & \\
\hline HOUSEHOLD CONFIDENCE & & $\begin{array}{c}0,061 \\
(0,072)\end{array}$ & \\
\hline LOAN TO DEPOSIT $\times$ PARENT, Q-4 & & & $\begin{array}{l}-0,027 \\
(0,016)^{*}\end{array}$ \\
\hline CAPITAL ADEQUACY $\times$ PARENT, Q-4 & & & $\begin{array}{l}-0,376 \\
(0,974)\end{array}$ \\
\hline LEVERAGE $\times$ PARENT, $Q-4$ & & & $\begin{array}{l}-1,433 \\
(0,685)^{\star *}\end{array}$ \\
\hline ROA $\times$ PARENT, Q-4 & & & $\begin{array}{l}4,419 \\
(1,983)^{\star *}\end{array}$ \\
\hline Konstans & $\begin{array}{l}79,498 \\
(17,918)^{* * *}\end{array}$ & $\begin{array}{c}48,916 \\
(29,672)^{*}\end{array}$ & $\begin{array}{l}129,123 \\
(25,195)^{* * *}\end{array}$ \\
\hline$N$ & 578 & 578 & 436 \\
\hline
\end{tabular}

Megjegyzés: a zárójelben Newey-West-féle standard hibák szerepelnek.

${ }^{* * *} 1$ százalékos, ${ }^{\star *} 5$ százalékos, ${ }^{\star} 10$ százalékos szinten szignifikáns. 


\section{Válsághatások}

A pénzügyi válság erőteljes hatással volt az egész régióra, és a banki hitelezési politikát is megváltoztatta (De Haas és szerzőtársai [2012], Sóvágó [2011], Banai és szerzőtársai [2010a], Fábián és szerzőtársai [2010]). A válság kezdetétől a banki hitelállományok csökkentek, és megváltozott a bankok helyzetének hitelezésre gyakorolt hatása is (például Temesváry [2014b]). A következőkben ezt az összefüggést vizsgáljuk úgy, hogy a válság kétértékủ változója és a korábbi magyarázó változók interakciójának hatását teszteljük.

A 6. táblázat összefoglalja a banki, az anyabanki tulajdonságok és a makrokörnyezet éves hiteldinamikára gyakorolt hatását, különválasztva a válságidőszakot és a válság előtti, normál időszakot. ${ }^{11}$

\section{6. táblázat}

A válsághatásokra kontrolláló modellspecifikációk

Függő változó: a banki hitelállomány éves százalékpontos változása

\begin{tabular}{|c|c|c|c|}
\hline & (1) & $(2)$ & (3) \\
\hline LOAN TO DEPOSIT, Q $-4 \times$ NO CRISIS & $\begin{array}{l}-0,104 \\
(0,023)^{\star * *}\end{array}$ & $\begin{array}{l}-0,105 \\
(0,023)^{* * *}\end{array}$ & $\begin{array}{l}-0,102 \\
(0,026)^{* * *}\end{array}$ \\
\hline LOAN TO DEPOSIT, Q- $4 \times$ CRISIS & $\begin{array}{l}-0,044 \\
(0,026)^{*}\end{array}$ & $\begin{array}{l}-0,041 \\
(0,027)\end{array}$ & $\begin{array}{l}-0,029 \\
(0,027)\end{array}$ \\
\hline FX SWAP, Q-4× NO CRISIS & $\begin{array}{c}0,054 \\
(0,124)\end{array}$ & $\begin{array}{c}0,089 \\
(0,138)\end{array}$ & $\begin{array}{l}-0,182 \\
(0,167)\end{array}$ \\
\hline FX SWAP, Q- $4 \times$ CRISIS & $\begin{array}{l}-0,005 \\
(0,080)\end{array}$ & $\begin{array}{c}0,018 \\
(0,075)\end{array}$ & $\begin{array}{c}-0,012 \\
(0,080)\end{array}$ \\
\hline LIQUID ASSET, Q- $4 \times$ NO CRISIS & $\begin{array}{l}-0,379 \\
(0,137)^{\star * *}\end{array}$ & $\begin{array}{l}-0,392 \\
(0,139)^{* * *}\end{array}$ & $\begin{array}{l}-0,392 \\
(0,142)^{\star * *}\end{array}$ \\
\hline LIQUID ASSET, Q-4 × CRISIS & $\begin{array}{c}-0,115 \\
(0,089)\end{array}$ & $\begin{array}{l}-0,029 \\
(0,084)\end{array}$ & $\begin{array}{l}-0,028 \\
(0,086)\end{array}$ \\
\hline $\begin{array}{l}\text { CAPITAL ADEQUACY, Q }-4 \times \\
\text { NO CRISIS }\end{array}$ & $\begin{array}{l}-0,180 \\
(0,331)\end{array}$ & $\begin{array}{l}-0,169 \\
(0,345)\end{array}$ & $\begin{array}{l}-0,187 \\
(0,355)\end{array}$ \\
\hline $\begin{array}{l}\text { CAPITAL ADEQUACY, Q }-4 \times \\
\text { CRISIS }\end{array}$ & $\begin{array}{c}0,201 \\
(0,149)\end{array}$ & $\begin{array}{c}0,289 \\
(0,158)^{*}\end{array}$ & $\begin{array}{l}0,412 \\
(0,181)^{\star *}\end{array}$ \\
\hline NPL $(Q \times 4) \times$ NO CRISIS & $\begin{array}{l}0,955 \\
(0,375)^{* *}\end{array}$ & $\begin{array}{l}0,890 \\
(0,395)^{* *}\end{array}$ & $\begin{array}{l}1,151 \\
(0,422)^{\star * *}\end{array}$ \\
\hline NPL $(\mathrm{Q} \times 4) \times$ CRISIS & $\begin{array}{l}-0,222 \\
(0,063)^{\star * *}\end{array}$ & $\begin{array}{l}-0,016 \\
(0,076)\end{array}$ & $\begin{array}{c}0,020 \\
(0,112)\end{array}$ \\
\hline $\begin{array}{l}\text { LOG TOTAL ASSETS, Q- } 4 \times \\
\text { NO CRISIS }\end{array}$ & $\begin{array}{l}-1,200 \\
(0,756)\end{array}$ & $\begin{array}{l}-0,921 \\
(0,935)\end{array}$ & $\begin{array}{l}-1,867 \\
(1,045)^{*}\end{array}$ \\
\hline LOG TOTAL ASSETS, Q-4 × CRISIS & $\begin{array}{l}-3,643 \\
(0,745)^{* * *}\end{array}$ & $\begin{array}{l}-3,310 \\
(0,675)^{* * *}\end{array}$ & $\begin{array}{l}-1,840 \\
(0,507)^{\star * *}\end{array}$ \\
\hline
\end{tabular}


A 6. táblázat folytatása

\begin{tabular}{|c|c|c|c|}
\hline & (1) & (2) & (3) \\
\hline PARENT, KÉTÉRTÉKÜ × NO CRISIS & $\begin{array}{c}2,905 \\
(2,778)\end{array}$ & $\begin{array}{c}3,205 \\
(2,993)\end{array}$ & $\begin{array}{c}2,074 \\
(3,316)\end{array}$ \\
\hline PARENT, KÉTÉRTÉKÜ × CRISIS & $\begin{array}{c}0,404 \\
(2,506)\end{array}$ & $\begin{array}{c}0,022 \\
(2,399)\end{array}$ & $\begin{array}{c}2,356 \\
(2,349)\end{array}$ \\
\hline GDP GROWTH $\times$ NO CRISIS & & $\begin{array}{c}0,159 \\
(0,330)\end{array}$ & \\
\hline GDP GROWTH $\times$ CRISIS & & $\begin{array}{l}1,121 \\
(0,441)^{* *}\end{array}$ & \\
\hline HUF/EUR $\times$ NO CRISIS & & $\begin{array}{c}0,058 \\
(0,064)\end{array}$ & \\
\hline HUF/EUR $\times$ CRISIS & & $\begin{array}{l}-0,022 \\
(0,039)\end{array}$ & \\
\hline BUBOR 3 MONTH $\times$ NO CRISIS & & $\begin{array}{c}0,153 \\
(0,478)\end{array}$ & \\
\hline BUBOR 3 MONTH $\times$ CRISIS & & $\begin{array}{l}2,325 \\
(0,602)^{* * *}\end{array}$ & \\
\hline $\begin{array}{l}\text { HOUSEHOLD CONFIDENCE } \times \\
\text { NO CRISIS }\end{array}$ & & $\begin{array}{c}0,028 \\
(0,105)\end{array}$ & \\
\hline $\begin{array}{l}\text { HOUSEHOLD CONFIDENCE } \times \\
\text { CRISIS }\end{array}$ & & $\begin{array}{l}-0,110 \\
(0,060)^{\star}\end{array}$ & \\
\hline MERGER, KÉTÉRTÉKÜ & $\begin{array}{l}45,786 \\
(7,741)^{* * *}\end{array}$ & $\begin{array}{l}45,886 \\
(7,838)^{* * *}\end{array}$ & $\begin{array}{l}46,588 \\
(6,519)^{* * *}\end{array}$ \\
\hline EARLYREPAYMENT & $\begin{array}{l}-4,558 \\
(0,719)^{\star * *}\end{array}$ & $\begin{array}{l}-6,982 \\
(0,886)^{* * *}\end{array}$ & \\
\hline Time fiXed effect & & & igen \\
\hline Konstans & $\begin{array}{l}57,468 \\
(12,723)^{* * *}\end{array}$ & $\begin{array}{c}36,097 \\
(19,077)^{*}\end{array}$ & $\begin{array}{l}61,889 \\
(18,888)^{* * *}\end{array}$ \\
\hline$R^{2}$ & 0,66 & 0,67 & 0,70 \\
\hline$N$ & 578 & 578 & 578 \\
\hline
\end{tabular}

Megjegyzés: a zárójelben a robusztus standard hibák szerepelnek.

${ }^{* * *} 1$ százalékos, ${ }^{\star *} 5$ százalékos, ${ }^{\star} 10$ százalékos szinten szignifikáns.

A korábbi becslésünkben némiképp meglepö eredmény volt, hogy a likvid eszközök aránya negatívan hatott a hitelezésre. Ezt azzal magyaráztuk, hogy a változó a kockázatvállalási hajlandóságot fogja meg, nem pedig a hitelezési képességet. A válsághatás vizsgálata megerősíti ezt. Az együttható ugyanis csak a válság előtti időszakban volt negatív és szignifikáns. A 2009-től kezdődő időszakban már nem volt szignifikáns hatása ennek a tényezőnek. Ezzel szemben a hitel/betét mutató mindkét időszakban szignifikáns és negatív hatással volt, bár az együttható némiképp csökkent a válságban. A 2009-2013-as időszakban egy százalékponttal magasabb hitel/ betét mutató már csak 0,04 százalékponttal alacsonyabb hitelállomány-növekedést 
indukált. Ez arra utal, hogy bár a Lehman-csőd utáni időszakban a bankoknak jelentős lépéseket kellett tenni, hogy prudens finanszírozási szerkezetet érjenek el, a 2009-2013-as periódus egészét figyelembe véve már nem a finanszírozási szerkezet a leginkább meghatározó tényező a hitelezésben.

A szolvenciahelyzetet mérő változók nem voltak szignifikánsak a teljes időszakra vonatkozó specifikációknál. Ezt a képet a válsághatás vizsgálata némiképpen árnyalja. Az NPL ráta - ami indirekt módon, de befolyásolja a szolvenciahelyzetet - hatása a válságban egyértelmüen negatív volt, míg a válság előtt pozitív. Ez utóbbit magyarázza, hogy a válság előtti időszakban nem volt jelentős NPL-állomány egyik banknál sem (a medián 3,6 volt), így nem jelentett terhet a pénzintézeteknek. Az NPL ebben az esetben ezért inkább a kockázatvállalási politikát jellemezte. Fontosabb azonban, hogy a válság után szignifikáns negatív hatást láttunk. Ez egybevág a korábbi cikkekkel (például Everaert és szerzőtársai [2015]), illetve a saját intuíciónkat is megerősíti. A nagy nem teljesítő állomány akadályozza az aktív hitelezést, így fontos célnak kell lennie a tisztítás támogatásának (Vienna Initiative [2012]). A szolvenciahelyzetet jellemző mutatók közül a tőkemegfelelési mutató (CAPITAL ADEQUACY) szignifikáns, pozitív hatással van a hitelezésre a válság kezdete óta. A SREP utáni tőkemegfelelési mutató 1 százalékpontos emelkedése 0,29-0,41 százalékponttal emeli a hitelállomány növekedési ütemét. Ezek az eredmények empirikusan is alátámasztják Banai és szerzőtársai [2010b] azon állítását, hogy bár közvetlenül a válság után jelentős problémát jelentett a bankok számára a likviditás hiánya, hosszú távon a szolvenciahelyzetük vált központi kérdéssé.

A tulajdonosi szerkezet hatása ebben a specifikációban sem volt szignifikáns, vagyis sem a válság előtt, sem a válság után nem találtunk különbséget a külföldi és a hazai tulajdonban levő bankok hitelezése között. Végül, a méret (тотAL ASSETS) hatása továbbra is negatív volt. A korábban említetteknek megfelelően ez technikai hatás, amit más tanulmányok is megerősítenek (Temesváry-Banai [2015], vagy Everaert és szerzőtársai [2015]).

A makrováltozóknak a korábbi specifikációkban nem volt egyértelmü, szignifikáns hatásuk. A válság hatásának vizsgálata azonban a makrohatások szempontjából is új információkat nyújt. A GDP-növekedésnek (GDP GROWTH) a 2008 utáni időszakban szignifikáns pozitív hatása volt. 1 százalékponttal magasabb növekedés 1,1 százalékponttal magasabb hitelállomány-növekedéssel járt együtt. A 3 hónapos Bubor ugyancsak szignifikáns pozitív hatást mutatott a válságban. A pozitív elöjelet az magyarázhatja, hogy a válság elején - elsősorban pénzügyi stabilitási indokok miatt - a kamatszint magas volt, a hitelezés drasztikus visszaesése viszont kissé később, 2009 végén indult el. 2010 és 2013 között már folyamatosan, egyenletes ütemben csökkent az állomány, függetlenül a kamatszinttől. Jól látható, hogy a makrokörnyezet inkább a válság alatt vált meghatározó tényezővé a hitelezésben, míg a banki változóknak ebben az időszakban csökkent a szignifikanciájuk. Ez arra utalhat, hogy a keresleti oldal hatása erösödött a válságban, és a kínálati oldalé csökkent (ellentmondva Everaert és szerzőtársai [2015] megállapításának). További empirikus vizsgálatok szükségesek azonban ennek az állításnak az alátámasztására. 


\section{Következtetések}

Tanulmányunkban a magyar bankrendszer hitelezési aktivitását magyarázó tényezőket vizsgáltuk. Ehhez egy olyan adatbázist állítottunk össze, amely tartalmazza az összes releváns banki tulajdonságot az 1998 és 2013 közötti időszakban. Az adatbázist kiegészítettük néhány fontos anyabanki tulajdonsággal is a külföldi tulajdonban lévő bankok esetében. Így lehetőségünk volt meghatározni, hogy mely banki, anyabanki, illetve makrotényezők befolyásolják leginkább a hitelezés alakulását. A reálgazdaság szempontjából is kiemelt jelentősége van a banki hitelezési aktivitásának, ezért fontos, hogy ilyen típusú mikroadatok segítségével is vizsgáljuk azt.

Az egyik legfőbb megállapításunk, hogy azon bankok voltak a legaktívabbak Magyarországon, amelyek képesek voltak belső megtakarításokra támaszkodni, és ebből finanszírozni a hitelezésüket. A prudens likviditási helyzet fontosságát más tényezők is megerösítették, hiszen például a devizacsere-piacra való ráutaltság csökkentette a hitelezési aktivitást. Több tanulmány is megállapította, hogy a külföldi és hazai tulajdonú bankok eltéröen viselkednek, a mi eredményeink azonban ellentmondanak ennek. A külföldi tulajdonos hatása nem volt szignifikáns a hitelezési aktivitásra. Az anyabankok helyzete azonban már befolyásolhatja a leánybanki aktivitást. Azok a bankok voltak aktívabbak a magyar piacon, amelyek tulajdonosa jobb tőkeellátottsággal, erősebb likviditási pozícióval és magasabb jövedelmezőséggel rendelkezett.

A válság hatását ugyancsak megvizsgáltuk. Azt találtuk, hogy 2009-től a likviditási pozíció háttérbe került, és a szolvenciahelyzet vált meghatározó tényezővé a hitelezésben. Ez empirikusan is bizonyítja Banai és szerzőtársai [2010b] megállapítását. Emellett azt láttuk, hogy a válság során megnőtt a makrováltozók magyarázó ereje, miközben az egyedi banki tulajdonságok hatása csökkent. Ez arra is utalhat, hogy a keresleti oldali tényezők relatíve fontosabbá váltak a válságban. Ezt az eredményt azonban a későbbiekben még érdemes tesztelni.

\section{Hivatkozások}

Abiad, A.-Dell'Ariccia, G.-Li, B. [2011]: Creditless recoveries. IMF Working Paper, WP/11/58. http://dx.doi.org/10.2139/ssrn.1787352.

Aydin, B. [2008]: Banking Structure and Credit Growth in Central and Eastern European Countries. IMF Working Paper, WP/08/215. http://dx.doi.org/10.5089/9781451870732.001.

BANAi ÁdÁm-Király Júlia-NAgy Márton [2010b]: The demise of the halcyon days in Hungary: "foreign" and "local" banks - before and after the crisis. BIS Papers, No. 54. http:// www.bis.org/publ/bppdf/bispap54l.pdf.

BANAi ÁdÁm-Király Júlia-VÁrhegyi Éva [2010a]: A rendszerváltás 20 évének egy egyedi fejezete: külföldi bankok dominanciája a kelet-közép-európai régióban, különös tekintettel Magyarországra. MNB-tanulmányok, 89. http://mek.oszk.hu/12100/12167/12167.pdf.

BAnai ÁdÁm-Kollarik András-Szabó-SolticzKy András [2013]: Az egynapos FX-swappiac topológiája. MNB-tanulmányok, 108. https://www.mnb.hu/letoltes/mt108.pdf.

Bijsterbosch, M.-Dahlhaus, T. [2011]: Determinants of Credit-less Recoveries. European Central Bank, Working Paper Series, No 1358. http://dx.doi.org/10.1007/s00181-014-0910-y. 
BIS [2013]: Basel III: The Liquidity Coverage Ratio and liquidity risk monitoring tools. Bank for International Settlements, Basel Committee on Banking Supervision, január, www.bis. org/publ/bcbs238.pdf.

BIS [2014]: Basel III: The net stable funding ratio. Bank for International Settlements. Basel Committee on Banking Supervision, október, http://www.bis.org/bcbs/publ/d295.pdf.

Cetorelli, N.-Goldberg, L. S. [2011]: Global banks and international shock transmission: Evidence from the crisis. IMF Economic Review, 59. 41-76. o. http://dx.doi.org/10.3386/ w15974.

Cornett, M. M.-McNutt, J. J.-Strahan, P. E.-Tehranian, H. [2011]: Liquidity risk management and credit supply in the financial crisis. Journal of Financial Economics, Vol. 101. No. 2. 297-312. o. http://dx.doi.org/10.1016/j.jfineco.2011.03.001.

De Haas, R.-Korniyenko, Y.-Loukoianova, E.-Pivovarsky, A. [2012]: Foreign banks and the Vienna Initiative: Turning sinners into saints? IMF Working Paper, 12/117. május, http://dx.doi.org/10.5089/9781475503463.001.

Everaert, G.-Che, N.-Geng, N.-Gruss, B.-Mpavido, G.-Lu, Y.-Saborowski, C.Vandenbussche, J.-Zeng, L. [2015]: Does Supply or Demand Drive the Credit Cycle? Evidence from Central, Eastern, and Southeastern Europe. IMF Working Paper, WP/15/15. http://dx.doi.org/10.5089/9781484379981.001.

FÁbián Gergely-Hudecz András-Szigel Gábor [2010]: A válság hatása a vállalati hitelállományokra Magyarországon és más kelet-közép-európai országokban. Hitelintézeti Szemle, 9. évf. 5. sz. 445-462. o.

Giannetti, M.-Laeven, L. [2012]: The flight home effect: Evidence from the syndicated loan market during financial crises. Journal of Financial Economics, Vol. 104. No. 1. 23-43. o. http://dx.doi.org/10.1016/j.jfineco.2011.12.006.

Hosszú ZsuzsannA-KöRmENDI GYÖNGY I-MéRő BENCE [2015]: Egy- és többváltozós szűrők a hitelrés alakulásának meghatározására. MNB-tanulmányok, 118. https://www.mnb.hu/ letoltes/mnb-tanulmany-hun-118.pdf.

KirÁly Júlia-NAgy MÁrton [2008]: Az amerikai subprime jelzálogpiac tanulságai a magyar piac számára. Hitelintézeti Szemle, 7. évf. 5. sz. 450-482. o.

Király Júlia-Nagy Márton-Szabó E. Viktor [2008]: Egy különleges eseménysorozat elemzése - a másodrendü jelzáloghitel-piaci válság és (hazai) következményei. Közgazdasági Szemle, 60. évf. 7-8. sz. 573-621. o.

MNB [2012]: Jelentés a pénzügyi stabilitásról. Magyar Nemzeti Bank, április.

Ongena, S.-Schindele Ibolya-Vonnák Dzsamilla [2014]: In lands of foreign currency credit, bank lending channels run through? The effects of monetary policy at home and abroad on the currency denomination of the supply of credit. CFS Working Paper Series, No. 474. http://dx.doi.org/10.2139/ssrn.2507688.

SóváGó SÁNDOR [2011]: Identifying supply and demand in the Hungarian corporate loan market. MNB Occasional Paper, 94. mek.oszk.hu/12200/12224/12224.pdf.

TEMEsváry Judit [2014a]: Foreign activities of U.S. banks since 1997: The roles of regulations and market conditions in crises and normal times. Journal of International Money and Finance, 56. http://dx.doi.org/10.1016/j.jimonfin.2014.09.008.

Temesváry Judit [2014b]: The Determinants of U.S. Banks' International Activities. Journal of Banking and Finance, 44. 233-247. o. http://dx.doi.org/10.1016/j.jbankfin.2014.04.014. Temesváry Judit-Banai Ádám [2015]: The Drivers of Foreign Bank Lending in Central and Eastern Europe: The Roles of Parent, Subsidiary and Host Market Traits. Kézirat, szeptember, http://dx.doi.org/10.2139/ssrn.2567705. 
Vienna Initiative [2012]: European Banking Coordination “Vienna Initiative” Working Group on NPLs in Central. Eastern and Southeastern Europe, március https://www.imf. org/external/region/eur/pdf/2012/030112.pdf.

\section{Függelék}

\section{F1. táblázat}

A főbb változók meghatározása

\begin{tabular}{|c|c|c|}
\hline Változó neve & Meghatározása & Forrás \\
\hline CREDIt GROWTH & A hitelállomány éves százalékos növekedése & $\mathrm{MNB}$ \\
\hline $\begin{array}{l}\text { LOAN TO DEPOSIT, } \\
\text { Q-4 }\end{array}$ & $\begin{array}{l}\text { Hitel/betét mutató - } \\
4 \text { negyedéves késleltetése }\end{array}$ & MNB \\
\hline FX sWAP, Q-4 & $\begin{array}{l}\text { Nettó devizacsere-állomány } \\
\text { a mérlegföösszeg arányában - } \\
4 \text { negyedéves késleltetés }\end{array}$ & MNB \\
\hline LIQUID ASSET , Q-4 & $\begin{array}{l}\text { Likvid eszközök a mérlegfőössze arányában - } \\
4 \text { negyedéves késleltetés }\end{array}$ & MNB \\
\hline $\begin{array}{l}\text { CAPITAL ADEQUACY, } \\
\text { Q-4 }\end{array}$ & $\begin{array}{l}\text { Tőkemegfelelési mutató a SREP után - } \\
4 \text { negyedéves késleltetés }\end{array}$ & MNB \\
\hline NPL, Q-4 & $\begin{array}{l}\text { NPL arány kockázati besorolás alapján - } \\
4 \text { negyedéves késleltetés }\end{array}$ & $\mathrm{MNB}$ \\
\hline $\begin{array}{l}\text { LOG TOTAL ASSETS, } \\
\text { Q-4 }\end{array}$ & $\begin{array}{l}\text { A mérlegfőösszeg logaritmusa - } \\
4 \text { negyedéves késleltetés }\end{array}$ & MNB \\
\hline $\begin{array}{l}\text { LOAN TO DEPOSIT } \times \\
\text { PARENT, Q-4 }\end{array}$ & $\begin{array}{l}\text { Hitel/betét mutató a tulajdonos } \\
\text { bankcsoportnál - } 4 \text { negyedéves késleltetés }\end{array}$ & $\begin{array}{l}\text { Bankscope és a bankok } \\
\text { pénzügyi beszámolói }\end{array}$ \\
\hline $\begin{array}{l}\text { CAPITAL ADEQUACY } \times \\
\text { PARENT, Q-4 }\end{array}$ & $\begin{array}{l}\text { Tőkemegfelelési mutató a tulajdonos } \\
\text { bankcsoportnál - } 4 \text { negyedéves késleltetés }\end{array}$ & $\begin{array}{l}\text { Bankscope és a bankok } \\
\text { pénzügyi beszámolói }\end{array}$ \\
\hline $\begin{array}{l}\text { LEVERAGE } \times \text { PARENT, } \\
\text { Q-4 }\end{array}$ & $\begin{array}{l}\text { Összes eszköz/tőke a tulajdonos } \\
\text { bankcsoportnál - } 4 \text { negyedéves késleltetés }\end{array}$ & $\begin{array}{l}\text { Bankscope és a bankok } \\
\text { pénzügyi beszámolói }\end{array}$ \\
\hline $\begin{array}{l}\mathrm{ROA} \times \mathrm{PARENT} \\
\mathrm{Q}-4\end{array}$ & $\begin{array}{l}\text { ROA a tulajdonos-bankcsoportnál - } \\
4 \text { negyedéves késleltetés }\end{array}$ & $\begin{array}{l}\text { Bankscope és a bankok } \\
\text { pénzügyi beszámolói }\end{array}$ \\
\hline GDP GROWTH & Éves nominális GDP-növekedés & $\mathrm{KSH}$ \\
\hline HUF/EUR & Forint/euró árfolyam & MNB \\
\hline BUBOR 3 MONTH & 3 hónapos Bubor éves átlaga & MNB \\
\hline $\begin{array}{l}\text { HOUSEHOLD } \\
\text { CONFIDENCE }\end{array}$ & Fogyasztói bizalmi indikátor & Eurostat \\
\hline
\end{tabular}


F2. táblázat

Leíró statisztikák

\begin{tabular}{lrrrrr}
\hline Változó & $N$ & Átlag & Szórás & Minimum & Maximum \\
\hline CREDIT GROWTH & 660 & 18,80 & 24,30 & $-32,59$ & 100,00 \\
LOAN TO DEPOSIT, Q-4 & 578 & 133,08 & 49,64 & 34,02 & 450,15 \\
FX SWAP, Q-4 & 627 & 6,04 & 8,44 & $-21,00$ & 36,00 \\
LIQUID ASSET, Q-4 & 627 & 17,28 & 8,25 & 1,00 & 45,00 \\
CAPITAL ADEQUACY, Q-4 & 627 & 12,55 & 7,92 & 2,00 & 86,00 \\
NPL, Q-4 & 627 & 6,45 & 6,05 & 0,00 & 28,00 \\
LOG TOTAL ASSETS, Q-4 & 627 & 13,55 & 1,27 & 8,62 & 16,02 \\
LOAN TO DEPOSIT $\times$ PARENT, Q-4 & 436 & 155,29 & 70,37 & 79,53 & 468,80 \\
CAPITAL ADEQUACY $\times$ PARENT, Q-4 & 436 & 11,88 & 2,01 & 7,40 & 17,80 \\
LEVERAGE $\times$ PARENT, Q-4 & 461 & 23,64 & 10,70 & 11,56 & 65,70 \\
ROA $\times$ PARENT, Q-4 & 461 & 0,34 & 0,55 & $-2,26$ & 2,04 \\
GDP GROWTH & 671 & 7,89 & 5,21 & $-2,87$ & 18,39 \\
HUF/EUR & 671 & 264,25 & 18,95 & 235,90 & 311,13 \\
HousEHOLD CONFIDENCE & 660 & $-0,01$ & 7,30 & $-29,60$ & 17,00 \\
BUBOR 3 MONTH & 671 & 9,09 & 3,11 & 4,28 & 18,11 \\
\hline
\end{tabular}




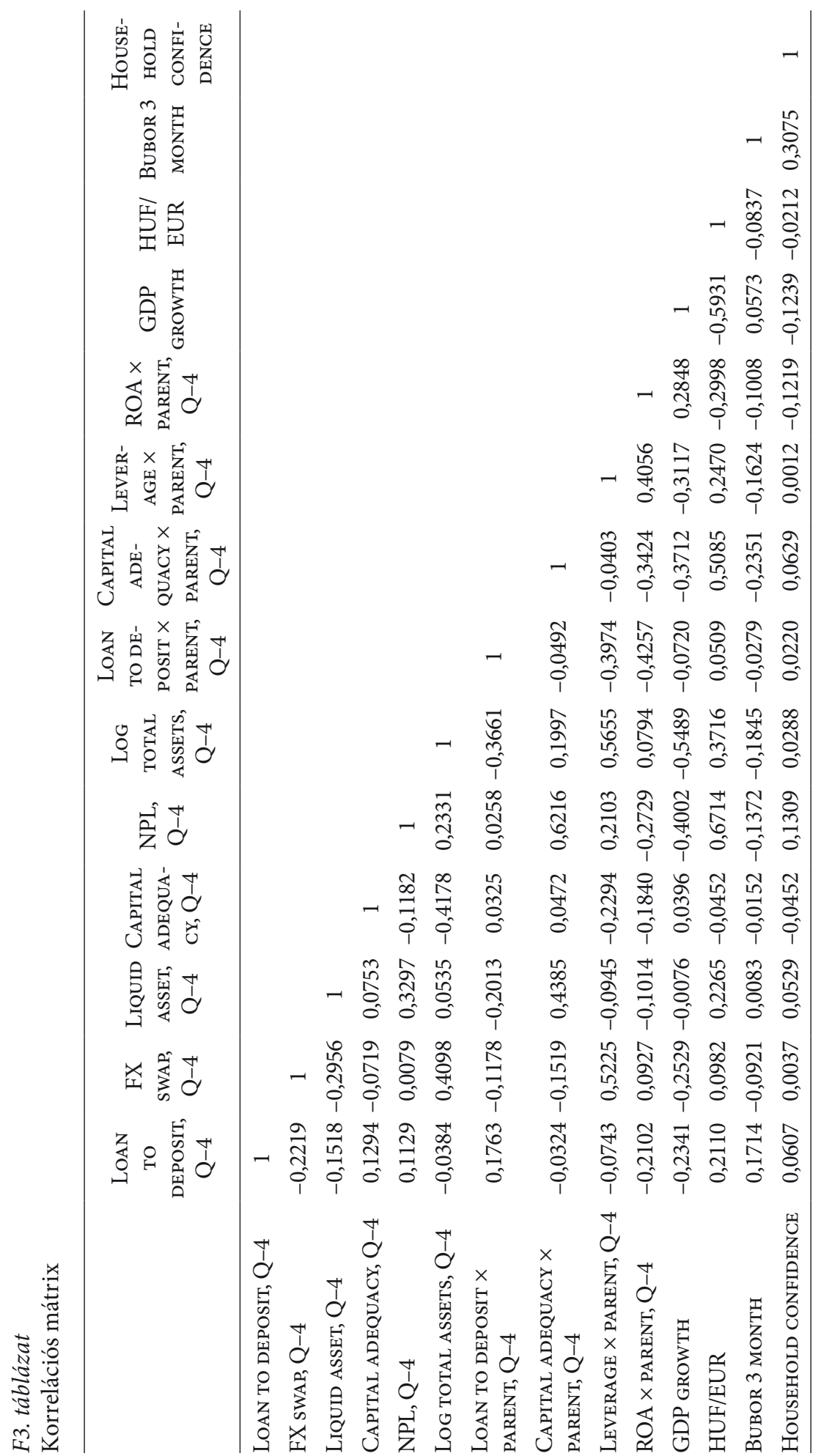

